This manuscript is a preprint currently under review in Journal of Hydrology. Hence, its final accepted version may be different from the current one. Once the manuscript will be fully published the corresponding DOI link will be added on the right-hand side of this webpage. Please, feel free to contact the corresponding author if you have any feedback 


\section{Evaluating precipitation datasets for large-scale distributed 2 hydrological modelling}

3 M. Mazzoleni ${ }^{1,2}$, L. Brandimarte ${ }^{3}$, A. Amaranto $^{4}$

4

$5 \quad{ }^{1}$ Department of Earth Sciences, Uppsala University, Uppsala, 75236, Sweden

$6 \quad{ }^{2}$ Centre of Natural Hazards and Disaster Science (CNDS), Sweden

$7{ }^{3}$ KTH Royal Institute of Technology, Department of Sustainable Development, Environmental

8 Sciences and Engineering, Stockholm, Sweden

$9{ }^{4}$ Department of Electronics, Information, and Bioengineering, Politecnico di Milano, Piazza

10 Leonardo da Vinci, Milano, Italy

Corresponding author: Maurizio Mazzoleni (maurizio.mazzoleni@geo.uu.se)

Keywords: Remote sensing, Distributed hydrological modelling, Precipitation datasets, largescale

\section{Abstract}

Over the past decades, a variety of valuable research studies has helped to advance our understanding of the advantages and limitations of satellite derived precipitation datasets as a forcing to hydrological models, in combination with or as an alternative to gauge data.

However, most studies have assessed the performance of only one single dataset (or a few), have used global precipitation datasets to force lumped models on regional/large-scale basins or have tested more complex distributed models only at small-scale basins. In addition, only few studies have re-calibrated the model for each precipitation dataset or have investigated reanalysisbased precipitation datasets.

We aimed at addressing these gaps in the literature: in particular, we compared the performance of 18 different precipitation datasets when used as main forcing in a grid-based distributed hydrological model to assess streamflow in medium to large-scale river basins. These datasets are classified as Uncorrected Satellites (Class 1), Corrected Satellites (Class 2) and Reanalysis - 
Gauges based datasets (Class 3). To provide a broad-based analysis, 8 large-scale river basins (Amazon, Brahmaputra, Congo, Danube, Godavari, Mississippi, Rhine and Volga) having different sizes, hydrometeorological characteristics, and human influence were selected. The distributed hydrological model was recalibrated for each precipitation dataset individually.

We found that there is not a unique best performing precipitation dataset for all basins and that results are very sensitive to the basin characteristics. However, a few datasets persistently outperform the others: SM2RAIN-ASCAT for Class 1, CHIRPS V2.0, MSWEP V2.1, and CMORPH-CRTV1.0 for Class 2, GPCC and WFEDEI GPCC for Class 3. Surprisingly, precipitation datasets showing the highest model accuracy at basin outlets do not show the same high performance in internal locations, supporting the use of distributed modelling approach rather than lumped.

\section{Introduction}

In a recent study about worldwide information on precipitation ground measurements, Kidd et al. (2017) estimated that "The total area measured globally by all currently available rain gauges is surprisingly small, equivalent to less than half a football field or soccer pitch". This limited gauge representativeness, the scarce and unequal spatial distribution of rain gauges (Maggioni and Massari, 2018) and the concern for the global decline of in-situ hydrologic measurements (Stokstad, 1999; Shiklomanov et al., 2002) have motivated increasing attention on the potentialities offered by the growing availability of satellite-retrieved precipitation products as an alternative source of input data in hydrological modelling. In particular, the interest for satellite products has grown over the past decade, with the increase in their temporal and spatial resolutions (Stephens and Kummerow, 2007; Kidd and Huffman, 2011; Xie and Xiong, 2011; Brocca et al., 2013; Funk et al., 2015; Duan et al., 2016; Beck et al., 2017a).

Since the first studies exploring the potentialities of incorporating satellite-based precipitation data (e.g., Barrett and Martin, 1981; Schulz, 1996; Tsintikidis et al., 1999) to the latest global-scale comprehensive evaluation of a number of precipitation datasets (Beck et al., 2017b), over the past three decades the scientific literature has produced a variety of valuable research works that have advanced our understanding of the advantages and limitations of satellite-derived precipitation information in hydrologic modelling. Recently, Maggioni and Massarri (2018) proposed a 
comprehensive review of previous studies on satellite-based precipitation input forcing hydrological models.

The performance of precipitation datasets in hydrological applications has been assessed by either comparing simulated and observed soil moisture (e.g., Brocca et al., 2013) or observed river discharge. Here we focus on the latter and group previous studies based on common approaches in performing their assessment.

Many studies focused their analysis on assessing the performance of a single precipitation dataset in hydrological modelling (e.g., Artna et al., 2007; Collischonn et al., 2008; Yang et al., 2017) or comparing the performance of few precipitation datasets in streamflow simulations (e.g., Yong et al., 2010; Bitew and Gebremichael, 2011; Behrangi et al., 2011; Falck et al., 2015, Camici et al., 2018), thus limiting their analysis to specific products.

Often, reanalysis-based precipitation datasets were not taken into account (e.g., Moazami et al., 2013; Zambrano-Bigiarini et al., 2017), or models were not re-calibrated for each precipitation dataset (e.g., Voisin et al., 2008; Su et al., 2008; Li et al., 2013), thus missing to compare uncorrected satellite products with the ones based on in-situ precipitation network.

Also, most of the previous studies have based the evaluation of precipitation datasets on hydrological models that are lumped/conceptual (e.g., Behrangi et al., 2011; Essou et al., 2016), thus not accounting for the inherent spatial variability of river basin characteristics that are averaged over the watershed (e.g., Boyle et al., 2001; Carpenter and Georgakakos, 2006).

On the other hand, studies implementing fully or semi distributed hydrological modelling refer only to a single specific case study (e.g., Stisen and Sandholt, 2010; Bitew et al., 2012; Pedinotti et al., 2012; Casse et al., 2015; Falck et al., 2015; Wang et al., 2015; Tang et al., 2016; Camici et al., 2018), or at sub-continental scale (e.g., Su et al. 2008; Li et al., 2013; Essou et al., 2016), thus missing the opportunity to generalize the results.

Furthermore, only a limited number of applications have explored the suitability of satelliteretrieved precipitation products in global/large-scale hydrological modelling (Fekete et al.; 2004 Voisin et al., 2008). A recent contribution from Beck et al. (2017b) performed a comprehensive global evaluation of 22 precipitation datasets using gauge observations and hydrological modeling. Nevertheless, these analyses did not explore the full range of available precipitation products (i.e.,Voisin et al., 2008), whose offer over the past fifteen years has greatly increased, and are 
performed based on lumped models (Beck et al., 2017b) or did not compare the results of the hydrological simulations with observed values (Fekete et al., 2004).

Our research questions emerged from the consideration that, notwithstanding the intrinsic uncertainty and errors associated to satellite retrieved precipitation data (e.g., Hossain and Anagnostou, 2004; Gottschalck et al., 2005; Hossain and Lettenmaier 2006; Hong et al., 2006; Ebert et al., 2007; Tian and Peters-Lidard 2010; Stampoulis and Anagnostou, 2012; Libertino et al., 2016; Maggioni and Massari, 2018), they represent a unique opportunity for hydrologic applications and, in particular, they can potentially spark light on improved flow estimation in data scarce or data poor basins (Serrat-Capdevilla et al., 2014).

We thus posed the following research questions, drawn from the highlighted gaps in the current literature:

a) How does precipitation estimation from satellite data using different products compare when forcing a distributed hydrologic model to estimate river discharge in basins with different spatial scales, climatic zones and human influence (e.g. presence of reservoirs)?

b) How does the density of the precipitation monitoring network used to correct (some) precipitation datasets affect river discharge estimation in different river basins?

c) Do spatial details gained by using distributed hydrological modelling and different precipitation datasets lead to an improved representation of the river flow within the basin?

d) Is there a specific dataset that always outperforms the other ones at both outlet and internal basin locations?

To reply to these research questions, we investigated the behaviour of 18 different alternative sources of rainfall data on estimating river discharges over large areas. In particular, we tested three classes of (quasi-) global precipitation dataset as main forcing of a grid-based distributed hydrological model: 1) satellite-based rainfall products; 2) gauge-corrected satellite rainfall products; and 3) reanalysis and gauge measured rainfall data. Eight large-scale river basins of different size and hydrometereological characteristics are used as case studies: Amazon, Brahmaputra, Congo, Danube, Godavari, Mississippi, Rhine and Volga river basins. 


\section{Material}

\section{Cases studies}

The eight river basins (see Figure 1) were selected based on different basin size, hydrometereological and climatic characteristics, presence of hydraulic structures and density of precipitation gauge network. We thus selected mid to large-scale river basins belonging to different continents and covering different climatic zones (Kottek et al. 2006). The Danube, Rhine and Mississippi basins have a dense network of precipitation gauges and a significant presence of dams and reservoirs which alter the natural hydrological response of the river basins. On the other hand, the Amazon, Congo and Volga basins can be considered less affected by human interventions. Table 1 (Molinier et al., 1993; Gaillardet et al, 1997; Wieriks and Schulte-Wulwer-Leidig, 1997; Goolsby and Battaglin, 2001; Immerzeel, 2008; Jha et al., 2009; Csagoly et al., 2016; Harrison et al., 2016) summarizes the main characteristics of each river, including climactic zones (Peel et al., 2007), size of the drainage area, length of the main river, average river flow, number of flow monitoring stations used to evaluate model performances (GRDC, 2018), number of reservoirs from the GRanDv1 dataset (Lehner et al., 2011) and percentage of human footprint (i.e., human population density, land transformation, electrical power infrastructure and access to land data, as reported in Center for International Earth Science Information Network, CIESIN) (Kareiva et al., 2007).

\section{Precipitation datasets}

We assessed the performance of 18 gridded precipitation datasets in hydrological modelling applications. In order to provide a fair comparison between datasets, we decided to classify them according to their data source (see Table 2). Among datasets exclusively based on uncorrected satellite data (Class 1) we analysed CHIRP V2.0 (Funk et al., 2015), CMORPH V1.0 (Joyce et al., 2004), PERSIANN (Sorooshian et al., 2000), PERSIANN-CCS (Hong et al., 2004), SM2RAINASCAT (Brocca et al., 2013), and TMPA 3B42 RT V7 (Huffman et al., 2007). In most applications, datasets of Class 1 were used as Near Real Time (NRT) products. We grouped in Class 2 gauge-corrected datasets: CHIRPS V2.0 (Funk et al., 2015), CMORPH-CRT V1.0 (Joyce et al., 2004), GPCP1DD V1.2 (Huffman et al., 2001), MSWEP V2.1 (Beck et al. 2017a), PERSIANN-CDR (Ashouri et al., 2015), and TMPA 3B42 V7 (Huffman et al., 2007). Finally, 

al., 2009), PFD (Sheffield et al., 2006), WFEDEI CRU (Weedon et al., 2014), and WFEDEI GPCC

145 (Weedon et al., 2014) belong to Class 3, reanalysis and gauge based datasets. It is worth noting 146 that these datasets have different spatial and temporal resolutions (see Table 2). The precipitation datasets are resampled to a spatial resolution of 0.25 degrees and a daily temporal resolution (Liu et al., 2017). In addition, because of the different temporal coverage of each dataset, the overlapping period between January $1^{\text {st }}, 2007$ and December $31^{\text {st }}, 2013$ was selected for calibration and validation analyses. A detailed review of different precipitation products is provided by Sun et al. (2018).

\section{Discharge dataset}

We calibrated and validated the hydrological models using river discharge data provided by the Global Runoff Data Centre (GRDC; http://www.bafg.de/GRDC/). The GRDC centre collects river discharge data for more than 9500 stations from 161 countries. The collection period varies spatially: the earliest data were from 1807, while the most recent were from 2018. In this study, the daily discharge data (from 2007 to 2013) for 46 sensors across 8 different river basins (as shown in Figure 1) were extracted from the whole GRDC database.

In particular, information from flow sensors located at the outlet of the 8 river basins were used to calibrate and validate the hydrological model. Flow values at internal sensors were used in the validation process of 5 of the 8 basins (Amazon, Danube, Godavari, Mississippi and Rhine) for which GRDC flow data were available within the catchment for the simulated period.

\section{Methodology}

\section{Distributed hydrological model}

In this study, a grid-based hydrological model was developed to spatially estimate the flow within river catchments with different spatial scales. Figure 2 shows a schematic representation of the proposed modelling framework. For each grid $\left(0.25^{\circ} \times 0.25^{\circ}\right.$ in this study), a conceptual HBV96 model (Bergström, 1992) was implemented to represent the rainfall-runoff processes and its grid output was then routed downstream using the widely known Muskingum model (Cunge 
1969). The choice of the HBV model was driven by its computational efficiency and its ability to provide accurate forecast under a wide range of climatic conditions (e.g. Merz and Bloschl, 2004; Bardossy, 2007; Jin et al., 2009; Demirel et al., 2015; Vetter et al., 2015). The connectivity between grids was estimated using the flow direction and flow accumulation dataset developed by $\mathrm{Wu}$ et al. (2011 and 2012).

The modelling steps implemented to calculate the discharge accumulation over the drainage network at time step $t$ are:

1-Calculate the flow contribute $Q_{R}$ generated in each grid of the basin, as response of rainfallrunoff processes using a conceptual lumped hydrological model.

2- Flows generated at the grids with lowest flow accumulation value (the most upstream part of the catchment) were propagated downstream using the Muskingum routing model following the connectivity characteristics (indicated as $Q_{P}$ in Figure 2).

3- The total discharge in each grid was calculated: let's consider cell $N$, showed in Figure 2, located downstream of cells $i$ and $j$. Once the upstream flows from grids $i$ and $j$ were routed at the downstream cell $N$, the total discharge at cell $N$ was calculated as:

$$
Q_{T}^{N}=Q_{R}^{N}+Q_{P}^{i}+Q_{P}^{j}
$$

where $Q_{R}$ is the generated flow from the conceptual hydrological model, $Q_{P}$ is the propagated flow from the upstream grids and $Q_{T}$ is the total flow at the cell $N$.

4- Discharge $Q_{T}$ at grid $N$ is then propagated at the downstream grids.

5-Steps from 2 to 4 were sequentially repeated for each flow accumulation values up to the highest one (i.e. the grid related to the basin outlet), in order to calculate the distributed discharge accumulation $Q_{C}$ within the catchment at the time step $t$.

A similar modelling framework is the widely used PCRaster software environment developed by Karssenberg et al. (2009) for constructing iterative spatiotemporal environmental and hydrological models (Bloschl et al, 2008; Cole and Moore, 2009; Thielen et al., 2009; PCraster, 2018).

It is worth noting that model states were initialized by running the model twice for the entire record. Despite the effect of model's initial condition has been widely discussed in the literature 
(see for example Goodrich et al., 1994; Minet et al., 2011; Seck et al., 2015) there is still no clear and automatic rule to determine the optimal spin-up time in hydrological models. However, according to Rahman et al., (2016), up to date modelling exercises are currently performed by running the simulation recursively through a specific period (which is typically a year) or by running the model multiple times for different climatological conditions. For this reason, we decided to initialize the states using two model runs. In addition, model states in each grid are independent from the neighbouring cells, and interactions occur only in the propagation of the generated total discharge.

For more information about the version of the HBV model implemented in this study, the readers are referred to Seiber and Vis (2002) and Beck et al. (2016).

\section{Performance measures}

The performance of the distributed hydrological model forced by the different precipitation input was calculated by means of the Nash Sutcliffe efficiency (NSE; Nash and Sutcliffe, 1970), and Bias index, widely used among hydrologists (Moriasi et al., 2007). The reason for using NSE instead of other indices as Root Mean Square Error, Pearson coefficient, or the Kling-Gupta efficiency was that NSE is highly sensitive to peak flow values (Krause et al., 2005; Beck et al., 2017b). In fact, the correct simulation of peak flows is highly dependent on different precipitation forcing used in hydrological modelling, which is the main objective of this study.

NSE value of 1 represents a perfect model simulation, while NSE value equal to 0 indicates that the model is as accurate as the mean of the observed flows. Ritter and Muñoz-Carpena (2013) indicated that models scoring NSE $\geq 0.65$ provide acceptable results.

The Bias index was selected to assess the tendency of the model to overestimate (Bias index greater than 1) or underestimate (Bias index smaller than 1) observed flow observations. The Bias index is calculated as the ratio between the mean of the simulated and observed flow values.

\section{Model calibration}

One of the main challenges in large-scale hydrological modelling is the proper estimation of model parameters (Anderton et al 2002). In the grid-based distributed model proposed in this study 14 model parameters need to be calibrated for each grid cell: 12 parameters from the HBV model and 2 from the Muskingum routing model. Here, we used the global regionalized dataset developed 
by Beck et al. (2016), spatially distributed and with a 0.25 degree resolution, to assign the initial values of the 12 parameters of the HBV model. These datasets were then individually perturbed by a correction coefficient, in order to estimate the optimal set of parameters for each different precipitation product and river basin. We re-calibrated the hydrological model for each precipitation dataset in order to get an unbiased and comprehensive comparison among the 231 datasets.

232 The 14 correction coefficients were calibrated by means of the least squares minimization 233 technique using the Broyden-Fletcher-Goldfarb-Shanno variant of the Davidon-Fletcher-Powell 234 minimization (DFPMIN) algorithm (Press et al., 1992). In particular, we aimed at maximizing the 235 NSE between the observed and simulated discharge values at the outlet, for all the considered 236 basins and precipitation datasets. This approach may be affected by “equifinality problem" (Beven 237 2001; 2002; Brooks et al., 2007) for large-scale basins in which calibration is performed using 238 only outlet discharge instead than flow measurements at internal points. However, due to the 239 limited flow information available at sensor locations within the catchments, we decided to use these measurements for model validation rather than calibration purposes.

The length and characteristic of the flood events used for model calibration have great influence on the estimation of the optimal model parameters. The calibration and validation periods are shown in Table 3. It can be noticed that for some basins the calibration period is posterior to the validation one, and vice versa: flood events included in the calibration period were specifically selected in order to properly represent the hydrological variability of the basin, both

246 in terms of high and low flow. In fact, previous studies demonstrated that applying a hydrological 247 model in flow conditions different than the ones in calibration would result in unreliable model 248 performances (Seibert 2003; Singh and Bardossy, 2012; Brigode et al., 2013). The validation of 249 the distributed hydrological model was then performed on independent periods. The results of the 250 calibration and validation analyses are showed in the next sections. 


\section{Results}

\section{Model calibration results}

Following the approach described in the previous section, the distributed hydrological model was calibrated for the 18 precipitation datasets, for each of the 8 river basins: 144 optimal sets of perturbation model parameters were calculated. The results of the calibration phase are first shown by class type of dataset (i.e., Class 1: satellite-based; Class 2: gauge-corrected and Class 3: reanalysis/gauge measured) and then individually for each precipitation dataset.

Figure 3 shows the average simulated flow for each dataset class against the observed flow hydrographs, at each basin's outlet. A qualitative assessment of the simulated hydrographs indicated that the proposed distributed model tends to properly represent the outlet flow when compared to the observed one. The model was able to correctly represent peaks and flood timing also in case of high flow variability, like on the Mississippi, Danube and Rhine basins (which are highly regulated basins as showed in Table 1).

Table 4 shows the average NSE values obtained comparing simulated and observed outlet flows. It can be observed that corrected satellites (Class 2) and reanalysis-gauges products (Class 3 ), provided the best model performance results. Class 1 outperformed the other two classes on the Amazon basin, while on the Brahmaputra basin all classes showed similar NSE values. This result may encourage the use of NRT products for river flow simulation on those large-scale basins in which no rain gauges can be used to correct satellite products of precipitation. On average, Class 2 provided the best results on basins characterized by a similar Tropical and Temperate-Arid climate like the Congo, Godavari and Mississippi basins (Peel et al., 2007). On the other hand, Class 3 products gave better NSE values on basins with Temperate and Temperate-Cold climate (e.g. Danube, Rhine and Volga) characterized by high values of human footprint.

The above results are related to the average NSE value over the datasets of each class type; Figure 4 shows the NSE values for each individual precipitation datasets analysed. It can be observed that no dataset outperforms the others, when comparing simulated and observed flows at basins outlets.

By looking at individual products in each class, we can conclude that CHIRP V2.0 (Class 1), CHIRPS V2.0 (Class 2) and CPC Global Unified (Class 3) are the datasets that provided the highest NSE values, equal to $0.74,0.77$, and 0.78 , respectively, when averaged over the 8 river 
basins. In contrast, the lowest average NSE values of $0.21,0.65$ and 0.54 were obtained with PERSIANN (Class 1), CMOPRH-CRT V1.0 (Class 2) and GSMaP-RNL (Class 3) respectively. These values refer to average NSE performance and the conclusions can change if river basins are considered individually. For example, the highest NSE values for the Brahmaputra basin were equal to $0.87,0.88$ and 0.89 for SM2RAIN-ASCAT (Class 1), MSWEP V2.1 (Class 2) and WFEDEI GPCC (Class 3). If we look at Figure 4 in terms of class behaviour, we can see that models forced by Class 1 NRT products tend to provide higher variability in NSE values and an overall mean NSE lower than the one obtained in case of Classes 2 and 3 products; while comparable performance results can be found between Class 2 and 3 products.

\section{Model validation results at basins outlets}

We validated the distributed hydrological model at basin outlets for time periods and durations different than in calibration. We present here our findings focusing on: a) model performance by forcing dataset over the eight case studies and b) model performance by river basin, highlighting the most and less performing forcing datasets.

\section{a) Analysis of the model performance by forcing dataset}

NSE values of each dataset obtained across the 8 basins are represented as boxplots in Figure 5. Overall, there is no a dataset outperforming the other ones. MSWEP V2.1 and GPCC were the datasets that provided the highest average NSE values for Classes 2 and 3, SM2RAIN-ASCAT for Class 1. Class 1 gave the highest variability of model results, which can be related to the difficulties of these products to properly represent precipitation in areas with complex topography and characterized by high spatiotemporal variability (Derin and Yilmaz, 2014). Among them, PERSIANN was the dataset providing the highest variability and the lowest NSE when used as input data. This can be due to the tendency of PERSIANN to overestimate observed precipitation (Tian et al., 2009), in particular in North America as demonstrated by Sun et al. (2018). SM2RAINASCAT and CHIRP V2.0 were the datasets (among the ones in Class 1) which lead to the best NSE (measured in terms of median value over the 8 basins) and lowest variability, respectively. Similar results were achieved by the distributed model forced with CMORPH V1.0 and PERSIANN-CCS. On average, datasets from Classes 2 and 3 gave the highest median NSE values and lowest variability of the performance index. A part from CMORPH-CRT V1.0 and TMPA 
3B42 V7, datasets of Class 2 provided similar NSE results, with MSWEP V2.1 outperforming all the other datasets in the class. This might be due to the fact that MSWEP V2.1 is developed by merging optimally daily gauge data, multiple satellite and reanalysis precipitation datasets. Instead, the other products of Class 2 are only based on in-situ gauges with coarser temporal resolution (Beck et al. 2017a). Regarding Class 3, the use of GSMaP-RNL as input in the distributed model produced low and more variable model performances if compared to other products in the same class. Comparable NSE values were obtained using CPC Global Unified, GPCC, PFD and WFEDEI CRU. As expected, the corrected satellite products CHIRPS V2.0, PERSIANN-CDR and TMPA 3B42 V7 gave higher model results and lower variability than their corresponding raw and real-time products CHIRP V2.0, PERSIANN-CCS and TMPA 3B42 RT V7 (Xie et al., 2017; Hussain et al., 2018). In general, we found that reanalysis products exhibit better performance at latitudes dominated by intense, localized convective precipitation systems, in agreement with Beck et al., 2017b.

\section{b) Analysis of the model performance by river basin}

Figure 6 summarizes the results obtained in validation, focusing on model performance for each basin: datasets providing the highest and lowest NSE values per each class are highlighted. The model was able to properly represent river flow at the Amazon basin outlet due to the periodical trend of the flow hydrograph. High median values of NSE were obtained for medium scale basins such as Rhine, Brahmaputra and Godavari. In addition, we can observe a higher variability of NSE values in basins with strong human impact, both in terms of number of reservoirs (e.g. Mississippi, Danube and Rhine) and human footprint (e.g. Volga). Low variability of the NSE values was obtained for the Amazon, Brahmaputra and Godavari basins. This can be related to the good ability of the distributed hydrological model to represent river flow in basins with low human influence (e.g. Amazon) and smaller size basin (e.g. Brahmaputra and Godavari).

For what concerns the comparison among different classes, Figure 6 shows that, when using uncorrected satellite products (Class 1, green bars in the figure) as input for the hydrological model, the highest variability in modelling performances was obtained in most of the basins. For example, high performance variability was obtained on the Mississippi basin using Class 1 datasets. This could be presumably due to the tendency of Class 1 products to provide results that are more variable in winter rather than in summer (as recently showed by Beck et al., 2019). In 
fact, one major challenge of Class 1 products is to properly represent snowfall and light rainfall occurring in winter (Kongoli et al., 2003; Liu and Seo, 2013; Habib et al., 2009; Tian et al., 2009; Beck et al., 2019). Classes 2 and 3 products gave NSE values higher than 0.5 for six out of the eight basins. However, the class providing the highest NSE depends on the considered basin, as shown also during calibration. In fact, Class 2 datasets gave highest median NSE values on the Godavari, Mississippi and Congo, which are basins characterized by Tropical and TemperateTropical climate. Similarly, reanalysis-gauges based products (Class 3), such as GPCC, WFEDEIGPCC and PFD, led to the best model results on the Danube, Rhine and Volga, respectively, in line with the results obtained in calibration. This can be due to the dense network of in-situ sensors used to derive Class 3 products. In addition, Class 3 datasets perform similarly in both summer and winter seasons.

These results are key to understand how different (quasi-) global precipitation datasets classes can be used to better force a distributed hydrological model for improving flood simulation, and which product in each class has lower variability in the model results for a particular river basin, with specific characteristics.

However, these conclusions are only valid when comparing simulated and observed discharge values at the outlet of the eight basins. For this reason, we performed additional analyses to compare simulated and observed flows also at sensors located at internal points. The results of this further analysis are described in the next section.

\section{Model validation results at internal locations}

In this analysis, only those basins (5 out of 8: Amazon, Danube, Godavari, Mississippi and Rhine) for which observed flow values in internal points were available from 2007 up to 2013 (the overlapping period of the 18 precipitation datasets) were considered. It is worth noting that we did not consider internal flow points located downstream of dam as flow variability may be strongly affected by regulation rules which were not accounted in the distributed hydrological model.

Our findings are presented focusing on: a) model performance by forcing dataset; b) model performance at different internal locations; c) model bias performance and d) best performing datasets. 
Figure 7 represents the boxplots of the NSE values comparing simulated and observed flow in both the internal locations and outlet of the 5 river basins. The variability of the NSE value drastically increases when considering model performances at internal locations. This is due to the fact that models were calibrated using only outlet flow information and no internal data.

As previously demonstrated during model calibration and validation at basin outlets, Class 1 datasets show higher variability in model performances, while Classes 2 and 3 products lead to results that are more comparable. Furthermore, no dataset constantly outperforms the others. In fact, model performances change according to the river basin and its characteristic. The highest average NSE values were achieved using TMPA 3B42 RT V7, GPCC, CMORPH-CRT V.10 and CHIRPS V2.0 for the Amazon, Danube, Godavari, Mississippi and Rhine, respectively. The good performances obtained using CHIRPS as model forcing may be due to the use of sub-monthly gauge observations to improve precipitation estimate and because CHIRPS is specifically designed to provide the most temporally homogeneous record possible (Beck et al., 2017a). Similar results for the TMPA 3B42 RT V7 datasets on the Amazon were obtained by Zubieta et al. (2015).

From the results reported in Figure 7, it can be observed that the distributed model was unable to reliably represent flow within the Mississippi river as a high variation of the NSE values is displayed for almost all the forcing datasets. In addition, the median values of the box-plot graph for the majority of the datasets are lower than zero, indicating poor model performances. This can be related to the inability of the model to properly represent hydrological processes in highly regulated basins (e.g. with high number dams) rather than bad performances of the precipitation datasets. Results that are more reliable were achieved in the other four basins. As previously 391 demonstrated, on the Amazon, datasets of Class 1 generally outperformed those in Classes 2 and 392 Class 3. This can be due to the systematic limitations of producuts from Class 3 in properly 393 detecting precipitation across South America (Sun et al., 2018).

On the Danube basin, both Classes 2 and Class 3 products showed NSE values higher than 0.5 , while on the Rhine basin there was higher variability of the median values of these two dataset 396 classes, which might be related to the high human influence on this basin. Moreover, corrected 397 satellites products (Class 2) gave, on the Godavari, higher median NSE values and lower 398 variability of model results than Class 3. 
For what concerns model results with respect to the spatial distribution of the sensors, Figure 8 represents the boxplots of the NSE values obtained at different sensor locations across all precipitation datasets. In addition, the human footprint at each internal gauge was represented using the dataset provided by Kareiva et al. (2007). Model performance at each location varied with the size of the basin. In fact, the variability of the median values of NSE at internal sensors of the basin was found higher when the size of the basin increases. This was clear for the Amazon and Mississippi rivers. Here, it was difficult to find a consistent spatial pattern of NSE values with respect to the order of the river reaches. For example, sensor 6 of the Amazon basin had higher median NSE of the boxplot graph than sensor 2 (downstream of sensor 6) and sensors 10 and 11 (upstream of sensor 6). On the contrary, sensor 12 had higher median NSE than both sensor 5 and 3 that are located downstream along that particular reach.

An additional remark is that model performances showed erratic behaviour in upstream sensors located in reaches converging into the same downstream reach. However, two main mechanisms can be found: (1) it can happen that both upstream reaches had lower NSE median values than the downstream sensor (e.g. downstream sensor 9 and upstream sensors 14 and 11 in the Mississippi basin; or downstream sensor 6 and upstream sensors 10 and 11 in the Amazon basin) or; (2), model performances at upstream reaches compensate each other, showing as an average resulting NSE value at the downstream sensor (e.g. downstream sensor 12 and upstream sensors 6 and 4 in the Mississippi basin).

419 It is interesting noting that no correlation was found between human footprint at each gauge location and model performance. As mentioned in the method section, the overall flow at a particular location is given by the sum of the flow generated by the model in that particular grid and the upstream contribute routed at the downstream location. For this reason, the flow value at a specific location is not affected by the high or low value of the human footprint in that location

424 as it may not be representative of the average value of human footprint within the basin (e.g. 425 upstream part of the basin), which has higher influence on the model performances. This is clear 426 in the Amazon basin, in which the majority of the basin has low human footprint (see Table 1), 427 but flow gauges are located in urbanized populated areas with higher human footprint close to the 428 river. 
Furthermore, the results of this analysis showed that model results at the basin outlets were higher than the ones at internal points of the basins. This was not surprising, since the model was calibrated at the outlet of each basin and no information from internal points was used during the calibration process. However, there were cases in which the model at internal locations performed better than at the outlet of the basin. In order to further investigate this aspect, Figure 9 represents the percentage of sensors in which NSE was higher at internal points (NSEI) than at the outlet of the basin (NSEO) for the different precipitation datasets.

The first visible result is that on the Amazon, Danube and Rhine basins only few precipitation datasets have a percentage of $\mathrm{NSE}_{\mathrm{I}}>\mathrm{NSE}_{\mathrm{O}}$ higher than zero. As already mentioned in the previous analyses, datasets belonging to Class 1 showed higher variability in model results (especially PERSIANN, PERSIANN-CCS, and CMORPH V1.0) and higher percentage of NSE $>\mathrm{NSE}_{\mathrm{O}}$ if compared to the other two datasets classes. This is evident in Figure 9 for the Mississippi and

Godavari basins. The latter shows a persistent percentage value of $\mathrm{NSE}_{\mathrm{I}}>\mathrm{NSE}_{\mathrm{O}}$ higher than 0: this is because simulated flow at sensor 4 (see Figure 8) always outperformed the model performances at the basin outlet.

\section{c) Analysis of the model bias performance}

To further assess model performance at internal points, Figure 10 illustrates the percentage of precipitation datasets, for each sensor location, that overestimates (Bias index greater than 1) the observed flow: this is called \%Bias in the following. The red circle indicates that $100 \%$ of datasets overestimates the observed flow, while $0 \%$ shows that all the precipitation datasets led to underestimation of the river flow at a particular sensor location.

A very interesting result is that, despite the fact that the NSE values are highly dependent on sensor location, the percentage of Bias index higher than 1 (called \%Bias in the following) was not influenced by the different dataset classes. In particular, the distributed model generally provided uniform Bias values on medium scale basins (Danube, Godavari and Rhine), while heterogeneous values were obtained on large-scale basins (Amazon and Mississippi). The model underestimated flow observations within the Rhine ( $4^{\text {th }}$ row) and Danube ( $5^{\text {th }}$ row) basins, regardless of precipitation product class; this behaviour could be attributed to high human influence on both basins. On the contrary, the model overestimated observed flow on the Godavari $\left(3^{\text {rd }}\right.$ row $)$. Different results were achieved for large-scale basins, Amazon ( $1^{\text {st }}$ row $)$ and Mississippi 
( $2^{\text {nd }}$ row). The former showed a flow underestimation of the distributed model on the Northern part of the basin, while the opposite occurred on the Southern reaches. Instead, for the Mississippi river basin the model seemed to overestimate observed flow. However, underestimation was also visible for the Eastern reaches of the basin.

An interesting aspect visible on the Amazon, Mississippi and Rhine basins is that sensors located at two upstream reaches converging into the basin outlet usually overestimated and underestimated the observed flow in the upstream reaches, and provided accurate results at the outlet. This phenomenon might be due to the model calibration, which focuses on optimised model parameters using flow outlet with the consequent compensation of flow at upstream opposite river reaches. This is clearly illustrated in Figure 11, where the ensemble of simulated flows using all the precipitation datasets is represented in red for overestimation (red arrow in the map, Bias index greater than 1.1), blue for underestimation (blue arrow, Bias index smaller than 0.9), and green for Bias index values close to 1 (green circle).

\section{d) Best performing datasets}

To conclude the assessment of model results at internal locations, in Figure 12 we show the datasets that provided the highest NSE value for each sensor location in each river basin. It can be observed that there was not a clear "winner" dataset, as it is showed in the validation analysis at the basin outlet. However, datasets of Class 2 often provide the highest NSE values. This can be due to the explicit use of daily gauge data for correcting satellite products. In particular, out of the 47 locations within the 5 river basins, Class 2 outperformed the other two classes 26 times (see Table 5). CHIRPS V2.0 (12 times), MSWEP V2.1 (7 times), CMORPH-CRT V2.0 (4 times) and PERSIANN-CDR ( 3 times) are the datasets in Class 2 that gave the highest NSE values. The higher model performances achieved with CHIRPS V2.0, MSWEP V2.1, and CMORPH-CRT V2.0 over PERSIANN-CDR can be related to the fact that PERSIANN-CDR indirectly incorporate gauge data.

Moreover, the model forced with CHIRPS V2.0 gave the highest NSE values in the Rhine and Mississippi basins, MSWEP V2.1 on both Mississippi and Danube basins, CMORPH-CRT V2.0 mainly in the Godavari basin, while PERSIANN-CDR on the Amazon basin. This suggests that using sub-monthly gauge observations improves precipitation products, and consequently flow simulation. In addition, the good performances of CHIRPS and MSWEPS V2.1 may be due to the 
489

490

491

492

493

494

495

496

497

498

499

500

501

502

503

504

505

506

507

508

509

use of high-resolution gauge-based climatic datasets to determine the most accurate long-term precipitation mean (Beck et al. 2017b).

Regarding Class 1 datasets, SM2RAIN-ASCAT provided the best results on the Amazon (at 4 sensors) and Danube (2 sensors). This result obtained with SM2RAIN-ASCAT on the Amazon was quite surprising as Massari et al. (2017) stated that soil moisture based rainfall estimates perform reasonably well in semi-arid climates rather than wet ones. We speculate that the good performance of SM2RAIN-ASCAT on the Amazon can be mainly driven by the model calibration and the optimal set of parameters used. TMPA 3B42 RT V7 and PERSIANN-CCS showed also high NSE values on the Amazon ( 3 times) as they provide a good precipitation estimate in wet tropical regions. Class 3 datasets gave high NSE values for 11 sensors of the five river basins. In particular, besides PFD, all datasets of Class 3 provided the highest NSE at least for one sensor in the basins. The results of this last analysis are collected in Table 5.

Another interesting result was that datasets producing the best model results at the basin outlet did not provide the highest model performances at internal sensor locations. For instance, on the Rhine basin the GPCC dataset allowed to achieve the highest model performance at the basin outlet, while at internal points the CHIRPS V2.0 dataset was the one showing the best model results in most of the cases. A similar pattern can be observed on the Mississippi river. This can be due to the better spatial representation of the precipitation field by the CHIRPS V2.0 dataset and to the fact that NSE index obtained at the basin outlet had comparable value as the one achieved with the best performing dataset. On the other hand, SM2RAIN-ASCAT and CMORPH-CRT V1.0 outperformed the other datasets in both basin outlets and on most of the internal locations of the Amazon and Godavari basins, respectively.

\section{Conclusions}

In this study, we compared the performance of 18 different precipitation datasets when used as main forcing in a grid-based distributed hydrological model to simulate river flow in large river basins. The 18 datasets were classified as Uncorrected Satellites (Class 1), Corrected Satellites (Class 2) and Reanalysis - Gauges based datasets (Class 3). To provide a broad-based analysis, 8 river basins (Amazon, Brahmaputra, Congo, Danube, Godavari, Mississippi, Rhine and Volga) having different sizes (medium to large), hydrometeorological characteristics, and human 
influences were considered. The distributed hydrological model was re-calibrated for each precipitation dataset individually.

The findings of this study underlined the importance of the proper selection of precipitation products for large-scale distributed hydrological modelling purposes. We showed that there is not a unique best performing precipitation dataset for all basins and results are very sensitive to the basin characteristics. However, few datasets persistently outperform the others, i.e. SM2RAINASCAT for Class 1, CHIRPS V2.0, MSWEP V2.1, and CMORPH-CRTV1.0 for Class 2, GPCC and WFEDEI GPCC for Class 3. The main findings of our study, related to the research questions that we originally posed, are:

1) The distributed hydrological model was able to properly represent river flow even if highly sensitive to differences in precipitation forcing (in agreement with Voisin et al. 2008). In particular, the model was mainly affected by the scale of the basin and by the human influence expressed as presence of reservoirs (see number of reservoirs in Table 1) and human footprint in the basin; different climatic zones had an indirect impact on the hydrological model through their influence on precipitation datasets;

2) Uncorrected Satellite datasets (Class 1), which can be considered as NRT products, provided the lowest and most variable model results when compared to the other two classes of products. SM2RAIN-ASCAT is the dataset that provided the best results within Class 1 products.

3) Precipitation datasets belonging to Class 2 outperformed the other datasets in basins with Tropical and Temperate-Arid climate (e.g. Congo, Mississippi and Godavari), while Class 3 datasets showed the highest NSE values in Temperate and Temperate-Cold basins (e.g. Danube, Rhine and Volga). In addition, datasets from Class 3 gave the best performances at basin outlets in case of dense precipitation monitoring networks, as in the Danube and Rhine basins.

4) Performance of model results decreased when comparing simulated distributed flows at internal basin locations with the observed ones. Higher variability of model results could be observed for large-scale basins like the Amazon and Mississippi. This can be due to the complex hydrometeorological characteristics and highly non-linear rainfall-runoff response (e.g. Mississippi basin, as described in Beck et al., 2017b). As expected, the highest NSE values were obtained at the basin outlets. 
5) Despite the different spatial results provided by the distributed model, the bias index value did not (significantly) change when using one class of dataset or the others.

6) Surprisingly, precipitation datasets showing the highest model result at the basin outlet did not provide a corresponding highest result at internal locations, supporting the use of distributed modelling approach rather than lumped. Overall, datasets from Class 2 provided the highest model results at internal basin locations.

Our conclusions are based on specific river basins (although large-scale and representing different parts of the globe), and a specific hydrological model (although distributed). Thus, to refine our findings, we suggest future studies on this field to: a) test other physically based distributed hydrological models; b) calibrate the hydrological model using also internal sensors; c) assess influence of different model spatial resolutions, d) better understanding on how the physical characteristics of the datasets might affect model results . Furthermore, in this study the values of the parameters are calibrated for each precipitation dataset. Consequently, we suggest for a future research direction to perform a global sensitivity analysis of distributed hydrological models to both input data and model parameters, in order to understand the spatial distribution of the governing principle of the hydrological processes and to guide the modeler towards an informed selection of the precipitation dataset.

The outcomes of this study are valuable to support the selection of precipitation dataset to achieve reliable model results for global and large-scale applications. This is the first research that attempts to model large-scale basins using multiple global datasets of precipitations within a distributed hydrological model. Our research offers promising results that might be key in assessing flow values in data scarce river basins.

\section{Acknowledgements}

The Authors gratefully thank the GRDC for providing the observed $Q$ data. This research was partly supported by the European Research Council (ERC) within the project "HydroSocialExtremes: Uncovering the Mutual Shaping of Hydrological Extremes and Society", ERC Consolidator Grant no. 761678. Part of this research was supported by the Swedish Strategic research programme StandUP for Energy. 


\section{Conflicts of Interest}

579 The authors declare no conflict of interest.

\section{Author contributions}

581 Conceptualization: M.M.; Data curation: M.M. and A.A.; Methodology. M.M. and L.B.; 582 Distributed Hydrological modelling: M.M.; Investigation: M.M., L.B. and A.A.; Original draft: 583 M.M.; Writing - review \& editing. M.M., L.B. and A.A 584 


\section{References}

Anderton S, Latron J, Gallart F. 2002. Sensitivity analysis and multi-response, multi-criteria evaluation of a physically based distributed model. Hydrological Processes 16(2):333-353. http://dx.doi.org/10.1002/hyp.336. http://dx.doi.org/10.1002/hyp.332.

Artan, G., Gadain, H., Smith, J.L., Asante, K., Bandaragoda, C.J., Verdin, J.P., 2007. Adequacy of satellite derived rainfall data for streamflow modeling. Nat.Hazards 43, 167-185.

Ashouri, H., Hsu, K., Sorooshian, S., Braithwaite, D. K., Knapp, K. R., Cecil, L. D., Nelson, B. R., and Pratt, O. P.: PERSIANNCDR: daily precipitation climate data record from multisatellite observations for hydrological and climate studies, B. Am. Meteorol. Soc., 96, 69-83, 2015.

Bardossy, A. (2007), Calibration of hydrological model parameters for ungauged catchments, Hydrol. Earth Syst. Sci., 11, 703-710.

Barrett, E.C., Martin D.W., 1981. The Use of Satellite Data in Rainfall Monitoring. Academic Press (London), $340 \mathrm{pp}$.

Beck, H. E., A. I. J. M. van Dijk, A. de Roo, D. G. Miralles, T. R. McVicar, J. Schellekens, and L. A. Bruijnzeel (2016), Global-scale regionalization of hydrologic model parameters, Water Resour. Res., 52, 3599-3622, doi: 10.1002/2015WR018247.

Beck, H.E., van Dijk, A.I., Levizzani, V., Schellekens, J., Miralles, D.G., Martens, B., de Roo, A., 2017a. MSWEP: 3-hourly 0.25 global gridded precipitation (1979-2015) by merging gauge, satellite, and reanalysis data. Hydrol. Earth Syst. Sci.21 (1), 589.

Beck, H. E., Vergopolan, N., Pan, M., Levizzani, V., van Dijk, A. I. J. M., Weedon, G. P., Brocca, L., Pappenberger, F., Huffman, G. J., and Wood, E. F.: Global-scale evaluation of 22 precipitation datasets using gauge observations and hydrological modeling, Hydrol. Earth Syst. Sci., 21, 6201-6217, https://doi.org/10.5194/hess-21-6201-2017, 2017b.

Beck, H. E., Pan, M., Roy, T., Weedon, G. P., Pappenberger, F., van Dijk, A. I. J. M., Huffman, G. J., Adler, R. F., and Wood, E. F.: Daily evaluation of 26 precipitation datasets using StageIV gauge-radar data for the CONUS, Hydrol. Earth Syst. Sci., 23, 207-224, https://doi.org/10.5194/hess-23-207-2019, 2019.

Behrangi, A., Khakbaz, B., Jaw, T.C., AghaKouchak, A., Hsu, K., Sorooshian, S., 2011. Hydrologic evaluation of satellite precipitation products over a mid-size basin. J. Hydrol. 397 (3-4), 225-237. 
Bergström, S.: The HBV model - its structure and applications, SMHI Reports RH 4, Swedish Meteorological and Hydrological Institute (SMHI), Norrköping, Sweden, 1992.

Beven K. 2001. How far can we go in distributed hydrological modelling? Hydrology and Earth System Sciences 5(1):1-12.

Beven K. 2002. Towards a coherent philosophy for modelling the environment. Proceedings of the Royal Society A-Mathematical Physical and Engineering Sciences 458(2026):2465-2484.

Bitew, M.M., Gebremichael, M., 2011. Assessment of satellite rainfall products for streamflow simulation in medium watersheds of the Ethiopian highlands. Hydrol. Earth Syst. Sci. 15, 1147-1155.

Bitew, M.M., Gebremichael, M., Ghebremichael, L.T., Bayissa, Y.A., 2012. Evaluation of highresolution satellite rainfall products through streamflow simulation in a hydrological modeling of a small mountainous watershed in Ethiopia. J. Hydrometeorol. 13, 338-350.

Bloschl, G., Reszler, C. R., and Komma, J.: A spatially distributed “ flash flood forecasting model, Environ. Mod. \& Soft., 23, 464- 478, 2008.

Boyle, D.B., Gupta, H.V., Sorooshian, S., Koren, V., Zhang, Z., Smith, M., 2001. Toward improved streamflow forecasts, value of semi-distributed modeling. Water Resources Research, 37 (11), 2749-2759.

Brigode, P., Oudin, L. Perrin, C. (2013) Hydrological model parameter instability: A source of additional uncertainty in estimating the hydrological impacts of climate change, Journal of Hydrology, 476, 410-425.

Brocca, L., Melone, F., Moramarco, T., Wagner, W., 2013. A new method for rainfall estimation through soil moisture observations. Geophys. Res. Lett. 40 (5), 853-858.

Brooks ES, Boll J, McDaniel PA. 2007. Distributed and integrated response of a geographic information system-based hydrologic model in the eastern Palouse region, Idaho. Hydrological Processes 21(1):110-122.

Camici, S., Ciabatta, L., Massari, C., and Brocca, L., How reliable are satellite precipitation estimates for driving hydrological models: A verification study over the Mediterranean area, Journal of Hydrology, 563, 950-961, 2018.

Carpenter, T.M., Georgakakos, K.P., 2006. Intercomparison of lumped versus distributed hydrologic model ensemble simulations on operational forecast scales. Journal of Hydrology, 329(1-2), 174-185. 
Casse, C., Gosset, M., Peugeot, C., Pedinotti, V., Boone, A., Tanimoun, B.A., Decharme, B., 2015. Potential of satellite rainfall products to predict Niger River flood events in Niamey. Atmos. Res. 163, 162-176.

Chen, M., Shi, W., Xie, P., Silva, V. B. S., Kousky, V. E., Higgins, R. W., and Janowiak, J. E.: Assessing objective techniques for gauge-based analyses of global daily precipitation, J. Geophys. Res., 113, D04110, https://doi.org/10.1029/2007JD009132, 2008.

Cole, S. J. and Moore, R. J.: Distributed hydrological modelling using weather radar in gauged and ungauged basins, Adv. Water Resour., 32, 1107-1120, 2009.

Collischonn, B., Collischonn, W., Tucci, C.E.M., 2008. Daily hydrological modeling in the Amazon basin using TRMM rainfall estimates. J. Hydrol. 360, 207-216.

Csagoly, P., Magnin, G., \& Hulea, O. (2016). Danube River Basin The Wetland Book (pp. 1-12): Springer.

Cunge, J. A. (1969). "On the subject of a flood propagation computation method (Muskingum method).” J. Hydraul. Res., 7(2), 205-230

Demirel, M. C., M. J. Booij, and A. Y. Hoekstra (2015), The skill of seasonal ensemble low-flow forecasts in the Moselle River for three different hydrological models, Hydrol. Earth Syst. Sci., 19(1), 275-291.

Derin, Y., \& Yilmaz, K. K. (2014). Evaluation of multiple satellite-based precipitation products over complex topography. Journal of Hydrometeorology, 15(4), 1498-1516.

Duan, Z., Liu, J., Tuo, Y., Chiogna, G., Disse, M., Evaluation of eight high spatial resolution gridded precipitation products in Adige Basin (Italy) at multiple temporal and spatial scales, Science of The Total Environment, 573, 1536-1553, 2016.

Ebert, E.E., Janowiak, J.E., Kidd, C., 2007. Comparison of near-real-time precipitation estimates from satellite observations and numerical models. Bull. Am. Meteorol. Soc. 88, 47-64. https://doi.org/10.1175/BAMS-88-1-47.

Essou, G. R. C., Arsenault, R., Brissette, F. P., 2016. Comparison of climate datasets for lumped hydrological modeling over the continental United States. J. Hydrol., 537, 334-345. https://doi.org/10.1016/j.jhydrol.2016.03.063, 2016.

Falck, Aline S. et al., 2015. Propagation of satellite precipitation uncertainties through a distributed hydrologic model: a case study in the Tocantins-Araguaia basin in Brazil. J. Hydrol. 527, 943957. 
Fekete, B. M., Vörösmarty, C. J., Roads, J. O., and Willmott, C. J.: Uncertainties in precipitation and their impacts on runoff estimates, J. Climate, 17, 294-304, 2004.

Funk, C., Peterson, P., Landsfeld, M., Pedreros, D., Verdin, J., Shukla, S., Husak, G., Rowland, J., Harrison, L., Hoell, A., and Michaelsen, J.: The climate hazards infrared precipitation with stations - a new environmental record for monitoring extremes, Scientific Data, 2, 150066, https://doi.org/10.1038/sdata.2015.66, 2015.

Gaillardet, J., Dupre, B., Allegre, C. J., \& Négrel, P. (1997). Chemical and physical denudation in the Amazon River Basin. Chemical geology, 142(3-4), 141-173.

Goodrich, D., Schmugge, T., Jackson, T., Unkrich, C., Keefer, T., Parry, R., Bach, L., and Amer, S.: Runoff simulation sensitivity to remotely sensed initial soil water content, Water Resour. Res., 30, 1393-1405, 1994.

Goolsby, D. A., \& Battaglin, W. A. (2001). Long term changes in concentrations and flux of nitrogen in the Mississippi River Basin, USA. Hydrological processes, 15(7), 1209-1226.

Gottschalck, J., Meng, J., Rodell, M., Houser, P., 2005. Analysis of multiple precipitation products and preliminary assessment of their impact on global land data assimilation system land surface states. J. Hydrometeorol. 6, 573-598. https://doi.org/10.1175/ JHM437.1.

Habib, E., Henschke, A., and Adler, R. F.: Evaluation of TMPA satellite-based research and realtime rainfall estimates during six tropical-related heavy rainfall events over Louisiana, USA, Atmos. Res., 94, 373-388, 2009.

Harrison, I. J., Brummett, R., \& Stiassny, M. L. (2016). Congo River Basin. The Wetland Book: II: Distribution, Description and Conservation, 1-18.

Hong, Y., Hsu, K.-L., Sorooshian, S., and Gao, X.: Precipitation Estimation from Remotely Sensed Imagery Using an Artificial Neural Network Cloud Classification System, J. Appl. Meteorol., 43, 1834-1853, 2004.

Hong, Y., Hsu, K. L., Moradkhani, H. and S. Sorooshian (2006). Uncertainty quantification of satellite precipitation estimation and Monte Carlo assessment of the error propagation into hydrologic response. Water resources research, 42(8).

Hossain, F., Anagnostou, E.N., 2004. Assessment of current passive-microwave- and infraredbased satellite rainfall remote sensing for flood prediction. J. Geophys. Res. 109, D07102. https://doi.org/10.1029/2003JD003986; Corrigendum, $110, \quad$ D06115, doi: 10.1029/2005JD005831. 
Hossain, F., Lettenmaier, D.P., 2006. Flood prediction in the future: Recognizing hydrologic issues in anticipation of the Global Precipitation Measurement mission. Water Resour. Res.42, W11301.

Huffman, G. J., Adler, R. F., Morrissey, M. M., Bolvin, D. T., Curtis, S., Joyce, R., McGavock, B., and Susskind, J.: Global precipitation at one-degree daily resolution from multi-satellite observations, J. Hydrometeorol., 2, 36-50, 2001.

Huffman, G. J., Bolvin, D. T., Nelkin, E. J., Wolff, D. B., Adler, R. F., Gu, G., Hong, Y., Bowman, K. P., and Stocker, E. F.: The TRMM Multisatellite Precipitation Analysis (TMPA): quasiglobal, multiyear, combined-sensor precipitation estimates at fine scales, $\mathrm{J}$. Hydrometeorol., 8, 38-55, 2007.

Hussain, Y., Satgé, F., Hussain, M.B. et al. Theor Appl Climatol (2018) 131: 1119. https://doi.org/10.1007/s00704-016-2027-z

Iguchi, T., Kozu, T., Kwiatkowski, J., Meneghini, R., Awaka, J., and Okamoto, K.: A Kalman filter approach to the Global Satellite Mapping of Precipitation (GSMaP) from combined passive microwave and infrared radiometric data, J. Meteorol. Soc. Jpn., 87A, 137-151, 2009.

Immerzeel, W. (2008). Historical trends and future predictions of climate variability in the Brahmaputra basin. International Journal of Climatology, 28(2), 243-254.

Jha, P. K., Tiwari, J., Singh, U. K., Kumar, M., \& Subramanian, V. (2009). Chemical weathering and associated $\mathrm{CO} 2$ consumption in the Godavari river basin, India. Chemical geology, 264(14), 364-374.

Jin, X., C. Xu, Q. Zhang, and Y. D. Chen (2009), Regionalization study of a conceptual hydrological model in Dongjiang basin, south China, Quat. Int., 208 (1-2), 129-137.

Joyce, R. J., Janowiak, J. E., Arkin, P. A., and Xi, P.: CMORPH: A method that produces global precipitation estimates from passive microwave and infrared data at high spatial and temporal resolution, J. Hydrometeorol., 5, 487-503, 2004.

Kareiva, P., Watts, S., McDonald, R. and Boucher, T. (2007) Domesticated Nature: Shaping Landscapes and Ecosystems for Human Welfare, Science, 316(5833), 1866-1869, DOI: $10.1126 /$ science. 1140170.

Karssenberg, D., Schmitz, O., Salamon, P., De Jong, C., and Bierkens, M. F. P.: A software framework for construction of process-based stochastic spatio-temporal models and data assimilation, Environ. Mod. \& Soft., 25, 1-14, doi:10.1016/j.envsoft.2009.10.004, 2009. 
Kidd, C. and Huffman, G. (2011), Global precipitation measurement. Met. Apps, 18: 334-353. doi:10.1002/met.284.

Kidd, C., Becker, A., Huffman, G.J., Muller, C.L., Joe, P., Skofronick-Jackson, G., Kirschbaum, D.B., 2017. So, how much of the Earth's surface is covered by rain gauges? Bull. Am. Meteorol. Soc. 98, 69-78. https:// doi.org/10.1175/BAMS-D-14-00283.1.

Kongoli, C., Pellegrino, P., Ferraro, R. R., Grody, N. C., and Meng, H.: A new snowfall detection algorithm over land using measurements from the Advanced Microwave Sounding Unit (AMSU), Geophys. Res. Lett., 30, https://doi.org/10.1029/2003GL017177, 2003.

Kottek, M., J. Grieser, C. Beck, B. Rudolf, and F. Rubel, 2006: World Map of the Köppen-Geiger climate classification updated. Meteorol. Z., 15, 259-263. DOI: 10.1127/09412948/2006/0130.

Krause, P., Boyle, D. P., and Bäse, F.: Comparison of different efficiency criteria for hydrological model assessment, Adv. Geosci., 5, 89-97, https://doi.org/10.5194/adgeo-5-89-2005, 2005.

Lehner, B., C. Reidy Liermann, C. Revenga, C. Vörösmarty, B. Fekete, P. Crouzet, P. Döll, M. Endejan, K. Frenken, J. Magome, C. Nilsson, J.C. Robertson, R. Rodel, N. Sindorf, and D. Wisser. 2011. High-Resolution Mapping of the World's Reservoirs and Dams for Sustainable River-Flow Management. Frontiers in Ecology and the Environment 9 (9): 494502.http://dx.doi.org/10.1890/100125.

Li, L., Ngongondo, C.S., Xu, C.Y., Gong, L., 2013. Comparison of the global TRMM and WFD precipitation datasets in driving a large-scale hydrological model in southern Africa. Hydrology Research, 44(5), 770-788.

Libertino, A., Sharma, A., Lakshmi, V., Claps, P., 2016. A global assessment of the timing of extreme rainfall from TRMM and GPM for improving hydrologic design. Environ. Res. Lett. $11,1$.

Liu, G. and Seo, E.-K.: Detecting snowfall over land by satellite high-frequency microwave observations: The lack of scattering signature and a statistical approach, J. Geophys. Res.Atmos., 118, 1376-1387, 2013.

Liu, X., Yang, T., Hsu, K., Liu, C., and Sorooshian, S.: Evaluating the streamflow simulation capability of PERSIANN-CDR daily rainfall products in two river basins on the Tibetan Plateau, Hydrol. Earth Syst. Sci., 21, 169-181, https://doi.org/10.5194/hess-21-169-2017, 2017. 
Maggioni, M. and Massari, C., 2018. On the performance of satellite precipitation products in riverine flood modeling: A review. J. Hydrol. 558, 214-224.

Massari, C., Crow, W., and Brocca, L.: An assessment of the performance of global rainfall estimates without ground-based observations, Hydrol. Earth Syst. Sci., 21, 4347-4361, https://doi.org/10.5194/hess-21-4347-2017, 2017.

Merz, R., and G. Bloeschl (2004), Regionalisation of catchment model parameters, J. Hydrol., 287 (1-4), 95-123.

Minet, J., Laloy, E., Lambot, S., andVanclooster, M.: Effect of high-resolution spatial soil moisture variability on simulated 5 runoff response using a distributed hydrolologic model, Hydrol. Earth Syst. Sci. 15, 1323-1338, 2011.

Moazami, S., Golian, S., Kavianpour, M. R., Hong, Y., 2013. Comparison of PERSIANN and V7 TRMM Multi-satellite Precipitation Analysis (TMPA) products with rain gauge data over Iran. Int. J. Remote Sens., 34, 8156-8171.

Molinier, M., Guyot, J.-L., De Oliveira, E., Guimarães, V., \& Chaves, A. (1995). Hydrologie du bassin de l'Amazone. Proc. Grands Bassins Fluviaux Péri-atlantiques, 1, 335-344.

Moriasi, D. N., Arnold, J. G., Van Liew, M. W., Bingner, R. L., Harmel, R. D., and Veith, T. L.: Model evaluation guidelines for systematic quantification of accuracy in watershed simulations, Transactions of the American Society of Agricultural and Biological Engineers, 50, 885-900, 2007.

Nash, J. E. and Sutcliffe, J. V.: River flow forecasting through conceptual models part I - a discussion of principles, J. Hydrol., 10, 282-290, 1970.

PCraster: Environmental Modelling language, available at: http:// pcraster.geo.uu.nl (last access: 01 December 2018), 2018.

Pedinotti, V., Boone, A., Decharme, B., Cr'etaux, J. F., Mognard, N., Panthou, G., Papa, F., Tanimoun, B. A., 2012.Evaluation of the ISBA-TRIP continental hydrologic system over the Niger basin using in situ and satellite derived datasets. Hydrol. Earth Syst. Sci., 16, 1745-1773.

Peel, M. C., Finlayson, B. L., and McMahon, T. A.: Updated world map of the Köppen-Geiger climate classification, Hydrol. Earth Syst. Sci., 11, 1633-1644, https://doi.org/10.5194/hess11-1633-2007, 2007.

Press, W.H., et al., 1992. Numerical recipes in FORTRAN. 2nd ed. Cambridge, UK: Cambridge University Press. 
803

804

805

806

807

808

809

810

811

812

813

814

815

816

817

818

819

820

821

822

823

824

825

826

827

828

829

830

831

832

Rahman, M. M., Lu, M., and Kyi, K. H.: Seasonality of hydrological model spin-up time: a case study using the Xinanjiang model, Hydrol. Earth Syst. Sci. Discuss., https://doi.org/10.5194/hess2016-316, in review, 2016.

Ritter A., Muñoz-Carpena, R. Performance evaluation of hydrological models: Statistical significance for reducing subjectivity in goodness-of-fit assessments, Journal of Hydrology, 480, 33-45, 2013.

Schamm, K., Ziese, M., Becker, A., Finger, P., Meyer-Christoffer, A., Schneider, U., Schröder, M., and Stender, P.: Global gridded precipitation over land: a description of the new GPCC First Guess Daily product, Earth Syst. Sci. Data, 6, 49-60, https://doi.org/10.5194/essd-6-492014, 2014.

Schultz, G.A., 1996. Remote sensing applications to hydrology: runoff. Hydrological Sciences Journal 41, 453-475.

Seck, A., Welty, C., and Maxwell, R. M.: Spin-up behavior and effects of initial conditions for an integrated hydrologic model, Water Resour. Res., 51, 2188-2210, https://doi.org/10.1002/2014WR016371, 2015.

Seibert, J. and Vis, M. J. P.: Teaching hydrological modeling with a user-friendly catchmentrunoff-model software package, Hydrol.Earth Syst. Sci., 16, 3315-3325, https://doi.org/10.5194/hess-16-3315-2012, 2012.

Seibert, J., 2003. Reliability of model predictions outside calibration conditions. Nordic Hydrology 34, 477-492. doi : 10.2166/nh.2003.028.

Serrat-Capdevila, A., Valdes, J.B., Stakhiv, E., 2014. Water management applications for satellite precipitation products: synthesis and recommendations. J. Am. Water Resour. Assoc. 50, 509525. https://doi.org/10.1111/jawr.12140.

Sheffield, J., Goteti, G., and Wood, E. F.: Development of a 50-year high-resolution global dataset of meteorological forcings for land surface modeling, J. Climate, 19, 3088-3111, 2006.

Shiklomanov, A.I., Lammers, R.B., Vörösmarty, C.J., 2002. Widespread decline in hydrological monitoring threatens pan-Arctic research. Eos, Transactions American Geophysical Union 83, 13.

Singh, K.S. and Bárdossy, A. (2012) Calibration of hydrological models on hydrologically unusual events, Advances in Water Resources, 38, 81-91. 
Sorooshian, S., Hsu, K.-L., Gao, X., Gupta, H. V., Imam, B., and Braithwaite, D.: Evaluation of PERSIANN system satellitebased estimates of tropical rainfall, B. Am. Meteorol. Soc., 81, 2035-2046, 2000.

Stampoulis, D., Anagnostou, E.N., 2012. Evaluation of global satellite rainfall products over continental Europe. J. Hydrometeorol. 13, 588-603. https://doi. org/10.1175/JHM-D-11086.1.

Stephens, G.L. and C.D. Kummerow, 2007: The Remote Sensing of Clouds and Precipitation from Space: A Review. J. Atmos. Sci., 64, 3742-3765,https://doi.org/10.1175/2006JAS2375.

Stisen, S., Sandholt, I., 2010. Evaluation of remote-sensing-based rainfall products through predictive capability in hydrological runoff modelling. Hydrol. Process. 24, 879-891.

Stokstad, E., 1999. Scarcity of rain, stream gages threatens forecasts. Science 285, 1199-1200.

Su, F., Hong, Y., Lettenmaier, D.P., 2008. Evaluation of TRMM Multisatellite Precipitation Analysis (TMPA) and its utility in hydrologic prediction in the La Plata basin. J. Hydrometeorol. 9, 622-640.

Sun, Q., Miao, C., Duan, Q., Ashouri, H., Sorooshian, S., \& Hsu, K.-L. (2018). A review of global precipitation data sets: Data sources, estimation, and intercomparisons. Reviews of Geophysics, 56, 79-107. https://doi.org/10.1002/2017RG000574.

Tang, G., Zeng, Z., Long, D., Guo, X., Yong, B., Zhang, W., Hong, Y., 2016. Statistical and hydrological comparisons between TRMM and GPM level-3 products over a midlatitude basin: Is day-1 IMERG a good successor for TMPA 3B42V7? J. Hydrometeorol. 17 (1), 121137.

Thielen, J., Bartholmes, J., Ramos, M.-H., and De Roo, A.: The European Flood Alert System Part 1: Concept and development, Hydrol. Earth Syst. Sci., 13, 125-140, doi:10.5194/hess-13125-2009, 2009.

Tian, Y., C. D. Peters-Lidard, J. B. Eylander, R. J. Joyce, G. J. Huffman, R. F. Adler, K. Hsu, F. J. Turk, M. Garcia,and J. Zeng (2009), Component analysis of errors in satellite-based precipitation estimates,J. Geophys. Res.,114, D24101,doi:10.1029/2009JD011949.

Tian, Y., Peters-Lidard, C.D., 2010. A global map of uncertainties in satellite-based precipitation measurement. Geophys. Res. Lett. 37 (24). 
Tsintikidis, D., Georgakakos, K.P., Artan, G.A., Tsonis, A.A., 1999. A feasibility study on mean areal rainfall estimation and hydrologic response in the Blue Nile region using METEOSAT images. Journal of Hydrology 221, 97-116.

Vetter, T., Huang, S., Aich, V., Yang, T., Wang, X., Krysanova, V., and Hattermann, F.: Multimodel climate impact assessment and intercomparison for three large-scale river basins on three continents, Earth Syst. Dynam., 6, 17-43, https://doi.org/10.5194/esd6-17-2015, 2015.

Voisin, N., Wood, A. W., and Lettenmaier, D. P.: Evaluation of precipitation products for global hydrological prediction, J. Hydrometeorol., 9, 388-407, 2008

Wang, S., S. Liu, X. Mo, B. Peng, J. Qiu, M. Li, C. Liu, Z. Wang, and P. BauerGottwein, 2015: Evaluation of Remotely Sensed Precipitation and Its Performance for Streamflow Simulations in Basins of the Southeast Tibetan Plateau. J. Hydrometeor., 16, 2577-2594, https://doi.org/10.1175/JHM-D-14-0166.1

Weedon, G. P., Balsamo, G., Bellouin, N., Gomes, S., Best, M. J., and Viterbo, P.: The WFDEI meteorological forcing data set: WATCH Forcing Data methodology applied to ERA-Interim reanalysis data, Water Resour. Res., 50, 7505-7514, 2014.

Wieriks, K., \& Schulte-Wülwer-Leidig, A. (1997). Integrated water management for the Rhine river basin, from pollution prevention to ecosystem improvement. Paper presented at the Natural Resources Forum.

Wu, H., J. S. Kimball, N. Mantua, and J. Stanford (2011), Automated upscaling of river networks for macroscale hydrological modeling, Water Resour. Res., 47, W03517, doi: 10.1029/2009WR008871.

Wu, H., J. S.Kimball, H.Li, M.Huang, L. R.Leung, and R. F.Adler (2012), A new global river network database for macroscale hydrologic modeling, Water Resour. Res., 48, W09701, doi:10.1029/2012WR012313.

Xie, P., and A.-Y. Xiong (2011), A conceptual model for constructing high-resolution gaugesatellite merged precipitation analyses, J. Geophys. Res., 116, D21106, doi: 10.1029/2011JD016118.

Xie, P., R. Joyce, S. Wu, S. Yoo, Y. Yarosh, F. Sun, and R. Lin, 2017: Reprocessed, BiasCorrected CMORPH Global High-Resolution Precipitation Estimates from 1998. J. Hydrometeor., 18, 1617-1641, https://doi.org/10.1175/JHM-D-16-0168.1. 
892

893

894

895

896

897

898

899

900

901

902

903

904

905

906

907

\section{6}

Yang, Y., Du, J., Cheng, L., Xu, W., 2017. Applicability of TRMM satellite precipitation in driving hydrological model for identifying flood events: a case study in the Xiangjiang River Basin, China. Nat Hazards, 87, 1489-1505. DOI 10.1007/s11069-017-2836-0

Yong, B., Ren, L. L., Hong, Y., Wang, J.H., Gourley, J.J., Jiang, S.H., Chen, X., Wang, W. 2010. Hydrologic evaluation of Multisatellite Precipitation Analysis standard precipitation products in basins beyond its inclined latitude band: A case study in Laohahe basin, China. Water Resources Research, 46(7), w07542.

Zambrano-Bigiarini, M., Nauditt, A., Birkel, C., Verbist, K., Ribbe, L., 2017. Temporal and spatial evaluation of satellite-based rainfall estimates across the complex topographical and climatic gradients of Chile. Hydrol. Earth Syst. Sci., 21, 1295-1320. https://doi.org/10.5194/hess-211295-2017, 2017.

Zubieta, R.,Geritana, A., Espinoza, J. C., and Lavado W.: Impacts of Satellite-based Precipitation Datasets on Rainfall-Runoff Modeling of the Western Amazon Basin of Peru and Ecuador, J. Hydrol., 528, 599-612, https://doi.org/10.1016/j.jhydrol.2015.06.064, 2015. 


\section{Tables}

909 Table 1. Overview of the characteristic of the 8 river basins selected as case studies.

\begin{tabular}{|c|c|c|c|c|c|c|c|}
\hline Basin & $\begin{array}{l}\text { Climatic } \\
\text { zone }\end{array}$ & $\begin{array}{c}\text { Basin Area } \\
\left(\mathrm{km}^{2}\right) \cdot \mathbf{1 0}^{3}\end{array}$ & $\begin{array}{l}\text { River length } \\
(\mathbf{k m})\end{array}$ & $\begin{array}{c}\text { Average } Q \\
\left(\mathrm{~m}^{3} / \mathrm{s}\right) \cdot 10^{3}\end{array}$ & $\begin{array}{c}\text { \# flow } \\
\text { sensors }\end{array}$ & $\begin{array}{c}\# \\
\text { reservoirs }\end{array}$ & $\begin{array}{c}\text { \% of human } \\
\text { footprint }\end{array}$ \\
\hline Amazon & Tropical & 6150 & 6992 & 209 & 12 & 8 & 8.6 \\
\hline Brahmaputra & $\begin{array}{l}\text { Temperate- } \\
\text { Cold }\end{array}$ & 525 & 2900 & 20 & 1 & 5 & 17.7 \\
\hline Congo & Tropical & 4000 & 4300 & 41 & 1 & 4 & 18.3 \\
\hline Danube & $\begin{array}{l}\text { Temperate- } \\
\text { Cold }\end{array}$ & 817 & 2857 & 7.1 & 7 & 175 & 39.9 \\
\hline Godavari & Tropical & 315 & 1465 & 3.4 & 4 & 58 & 34.6 \\
\hline Mississippi & $\begin{array}{l}\text { Temperate- } \\
\text { Arid }\end{array}$ & 3000 & 3800 & 17 & 16 & 698 & 27.9 \\
\hline Rhine & Temperate & 200 & 1223 & 2.9 & 8 & 24 & 43.7 \\
\hline Volga & $\begin{array}{l}\text { Temperate- } \\
\text { Subpolar }\end{array}$ & 1300 & 3700 & 8.1 & 1 & 16 & 28.6 \\
\hline
\end{tabular}

910

911 
Table 2. Overview of the 18 (quasi-) global precipitation datasets used as main forcing of the distributed hydrological model; the 913 acronym NRT indicates Near Real Time.

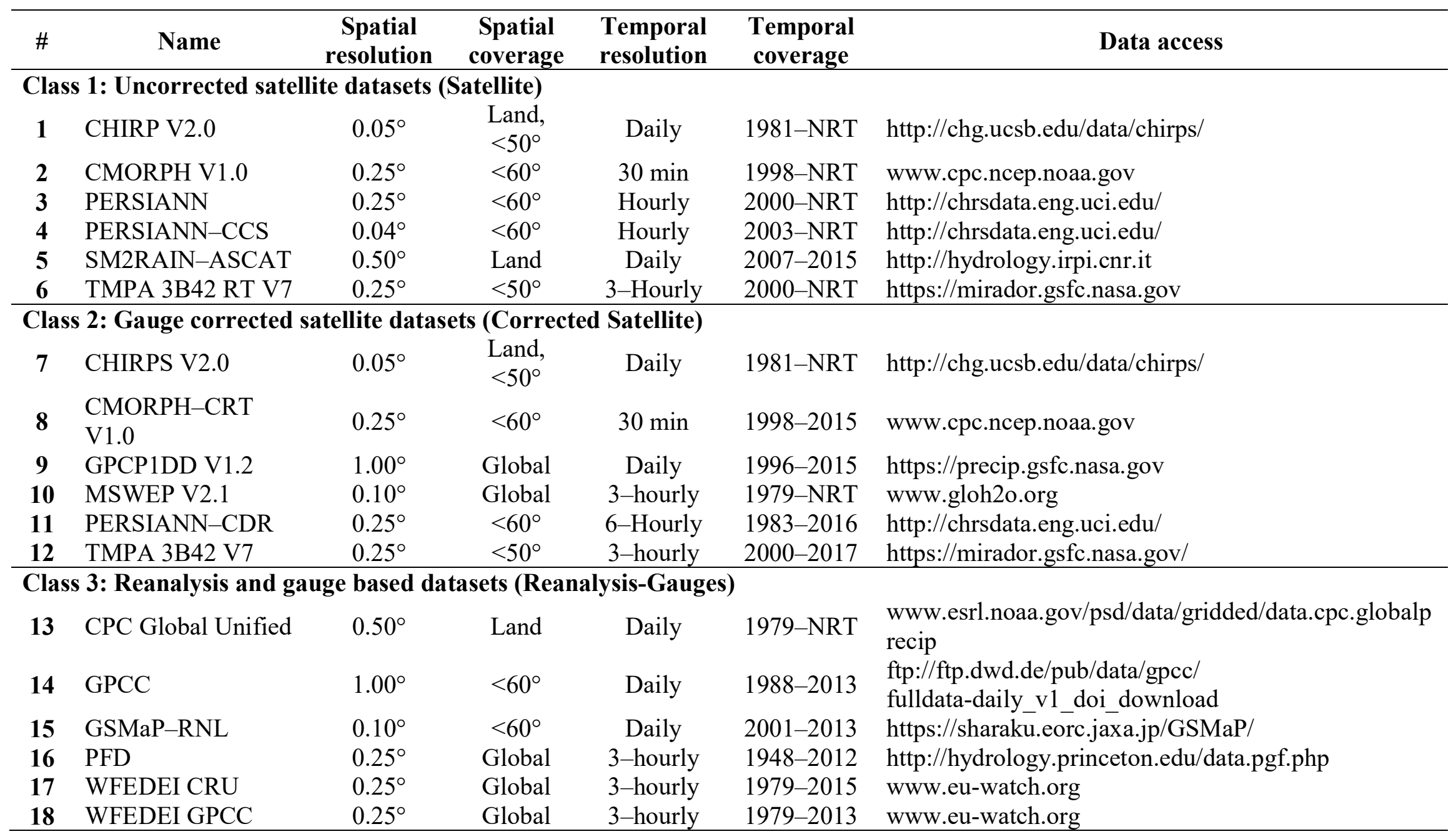


Table 3. Calibration and validation periods for the different basins.

\begin{tabular}{lcccc}
\hline & \multicolumn{2}{c}{ Calibration } & \multicolumn{2}{c}{ Validation } \\
\hline \multicolumn{1}{c}{ Basin } & Start & End & Start & End \\
\hline Amazon & $01-01-2007$ & $31-12-2009$ & $01-01-2010$ & $31-12-2013$ \\
Brahmaputra & $01-01-2007$ & $31-12-2009$ & $01-01-2010$ & $31-12-2012$ \\
Congo & $01-01-2007$ & $31-08-2010$ & $01-01-2010$ & $31-12-2013$ \\
Danube & $01-01-2009$ & $31-12-2010$ & $01-01-2007$ & $31-12-2008$ \\
Godavari & $01-01-2010$ & $31-12-2013$ & $01-01-2007$ & $31-12-2009$ \\
Mississippi & $13-04-2010$ & $31-12-2013$ & $01-01-2008$ & $31-12-2010$ \\
Rhine & $01-01-2008$ & $19-05-2011$ & $20-05-2011$ & $31-12-2013$ \\
Volga & $01-01-2007$ & $31-12-2008$ & $01-01-2009$ & $31-12-2010$ \\
\hline
\end{tabular}

916

917 
918 Table 4. Average NSE calibration values obtained comparing the observed flow at the basin 919 outlets with the average simulated flow using different datasets classes.

\begin{tabular}{lccc}
\hline \multicolumn{1}{c}{ Basin } & Class 1 & Class 2 & Class 3 \\
\hline Amazon & 0.92 & 0.89 & 0.89 \\
Brahmaputra & 0.84 & 0.83 & 0.83 \\
Congo & 0.46 & 0.72 & 0.63 \\
Danube & 0.50 & 0.83 & 0.85 \\
Godavari & 0.85 & 0.89 & 0.88 \\
Mississippi & 0.50 & 0.85 & 0.84 \\
Rhine & 0.56 & 0.77 & 0.84 \\
Volga & 0.55 & 0.49 & 0.78 \\
\hline
\end{tabular}

920

921 


\begin{tabular}{lcc}
\hline \multicolumn{1}{c}{ Dataset } & \# of highest NSE & Class \\
\hline CHIRPS V2.0 & 12 & 2 \\
MSWEP V2.1 & 7 & 2 \\
SM2RAIN-ASCAT & 6 & 1 \\
CMORPH-CRT V2.0 & 4 & 2 \\
GPCC & 3 & 3 \\
PERSIANN-CDR & 3 & 2 \\
WFEDEI GPCC & 3 & 3 \\
TMPA 3B42 RT V7 & 2 & 1 \\
PERSIANN-CCS & 2 & 1 \\
WFEDEI CRU & 2 & 3 \\
GSMaP-RNL & 2 & 3 \\
CPC Global Unified & 1 & 3 \\
\hline
\end{tabular}

924

925

926 


\section{Figures}

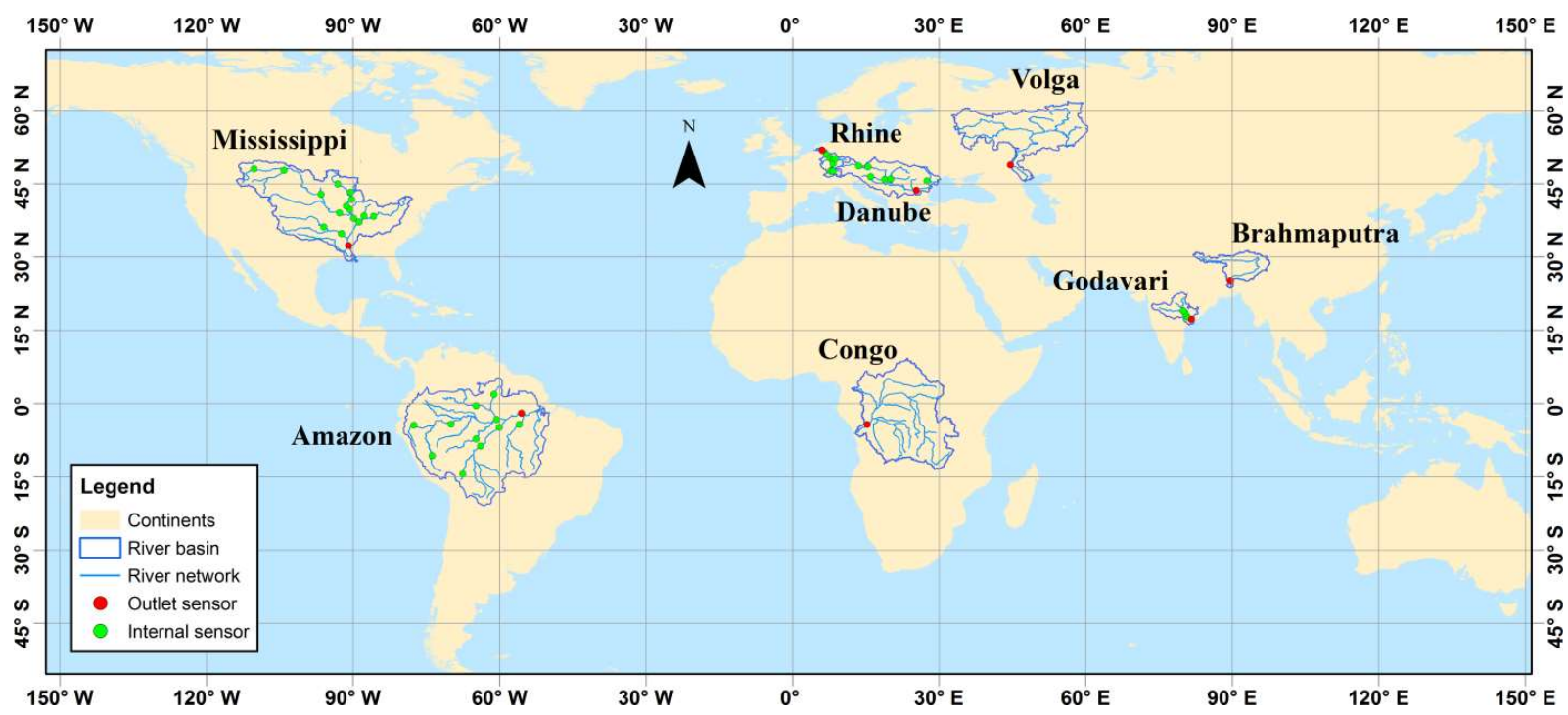

$929 \quad$ Figure 1. Case studies and in-situ streamflow sensors locations. 


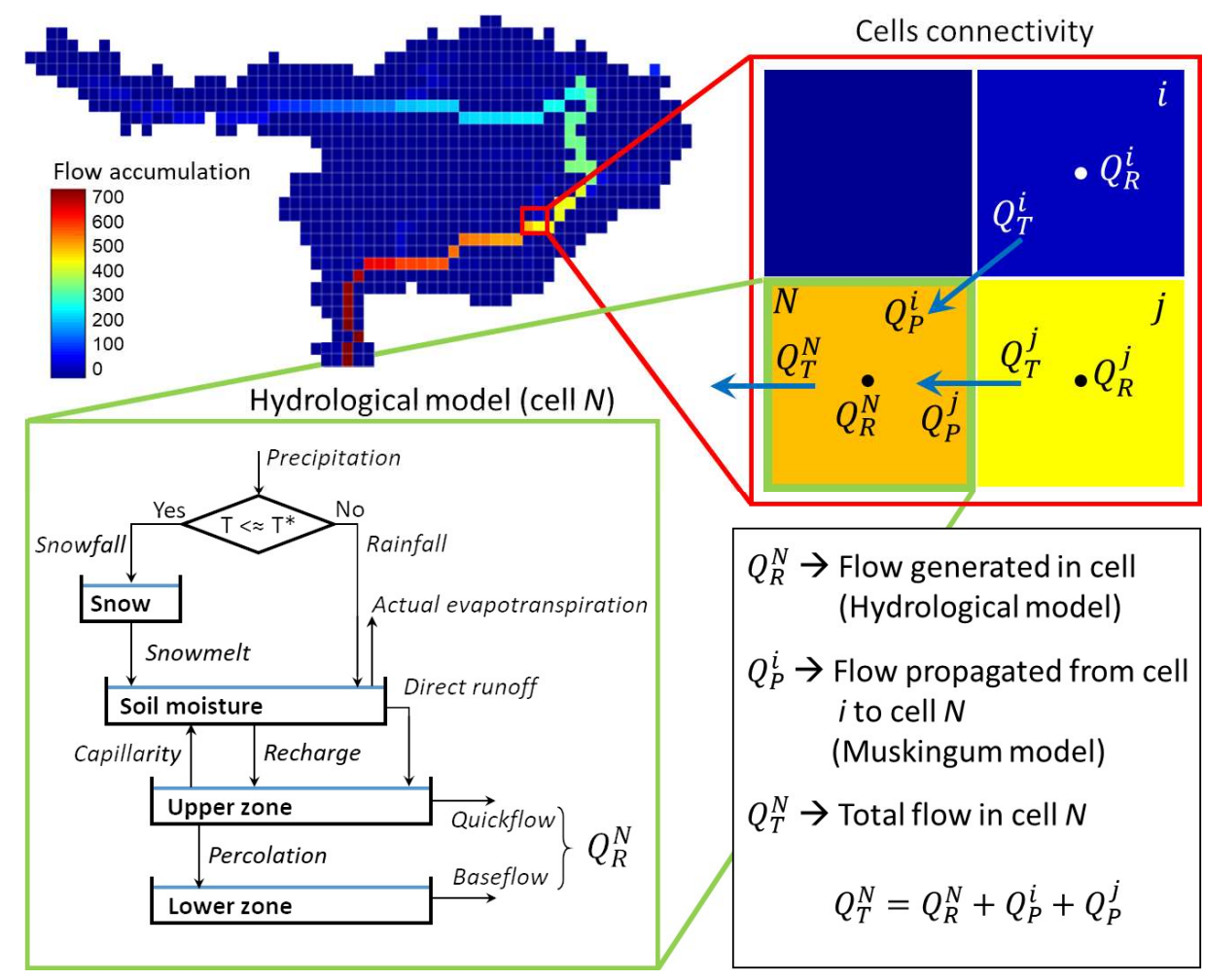

Figure 2. Distributed modelling framework: the flow accumulation map is used to assess the cell connectivity and propagate downstream the grid flow generated by rainfall-runoff processes. 
936
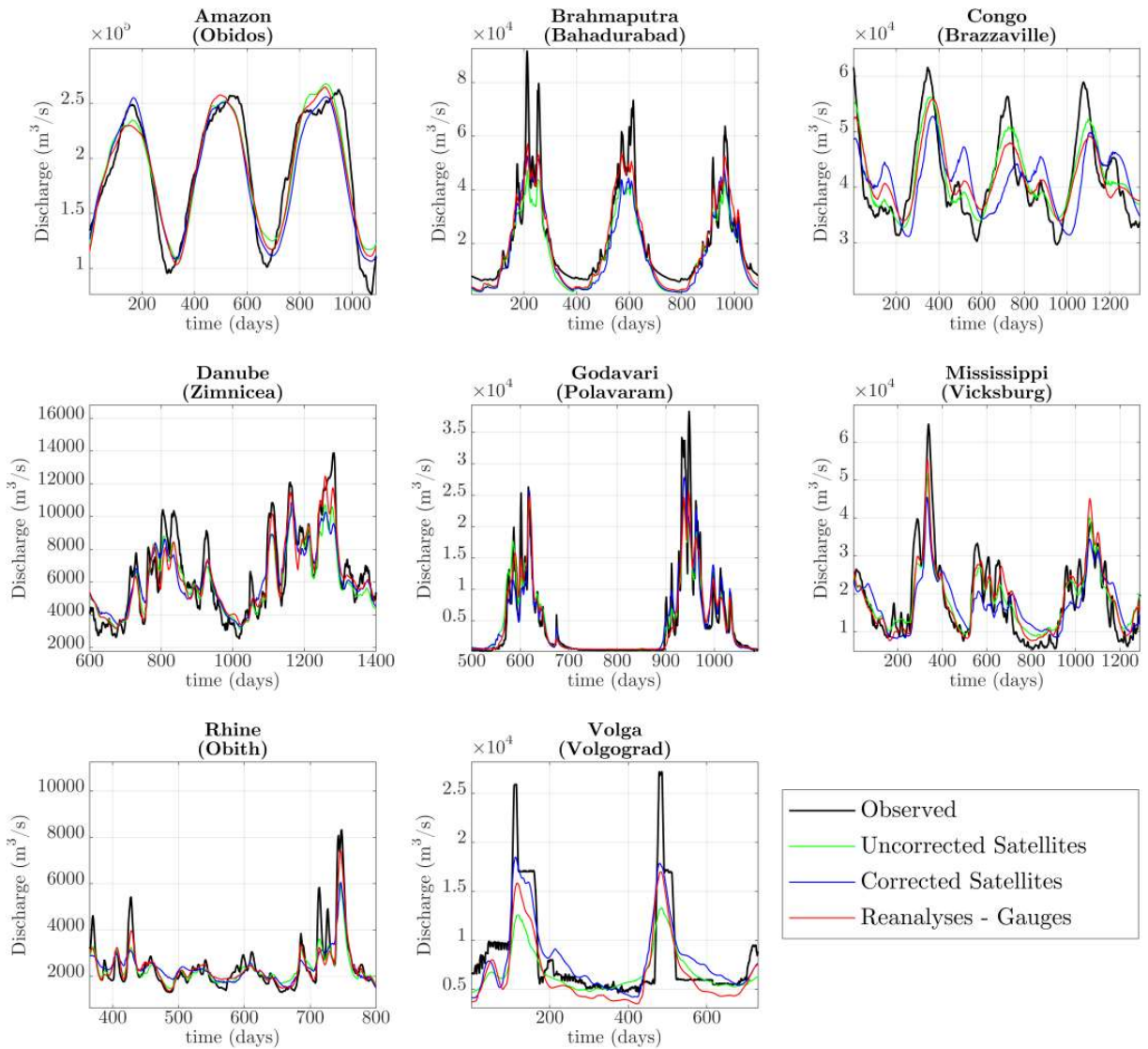

Figure 3. Comparison between observed and average simulated flow using precipitation datasets of classes 1, 2 and 3 at different basin outlets (in brackets the name of the stations). 


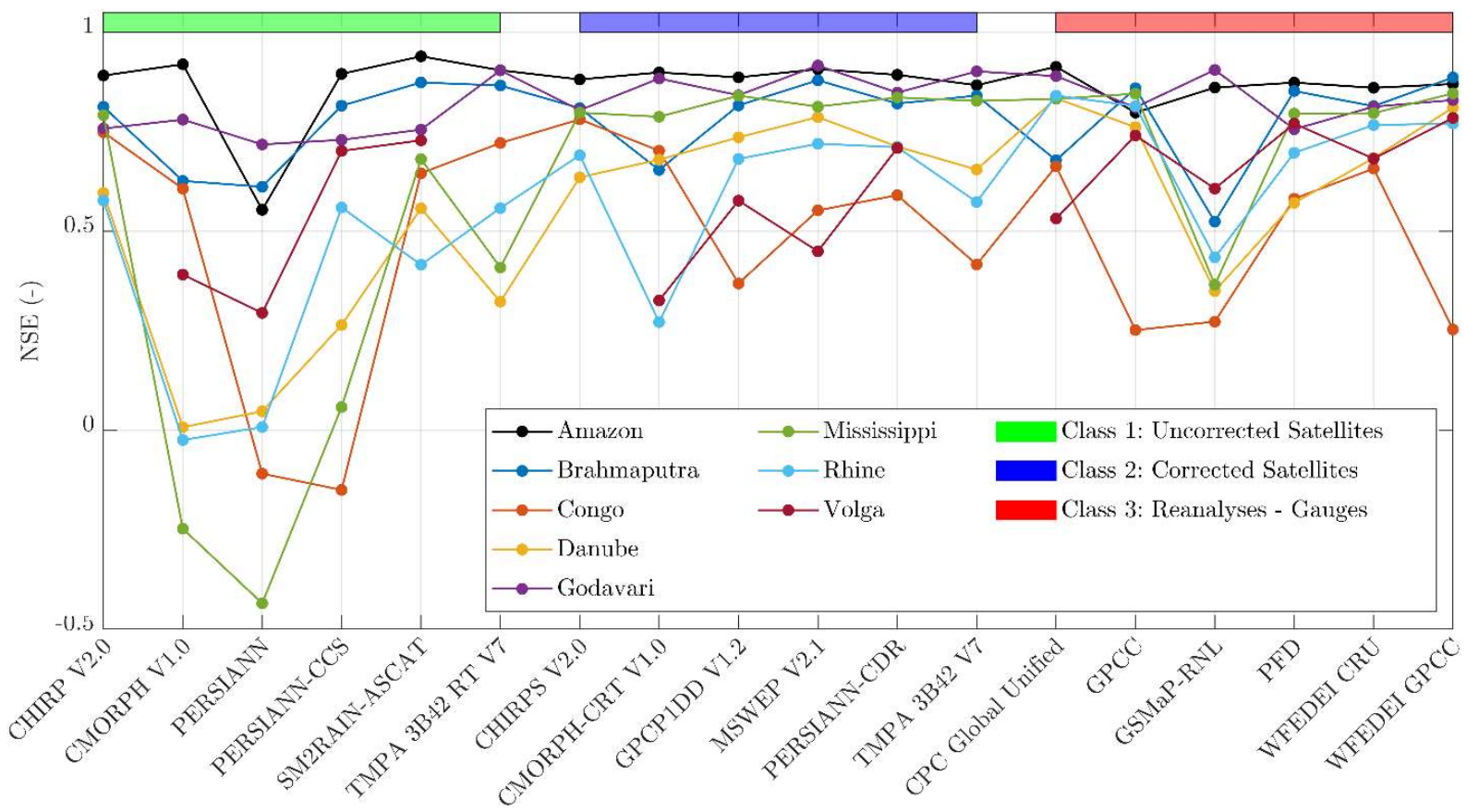

942 Figure 4. NSE values from calibration, calculated comparing the simulated flow obtained 943 using different datasets as input in the distributed hydrological model and observed flow at the 944 different basin outlets. 


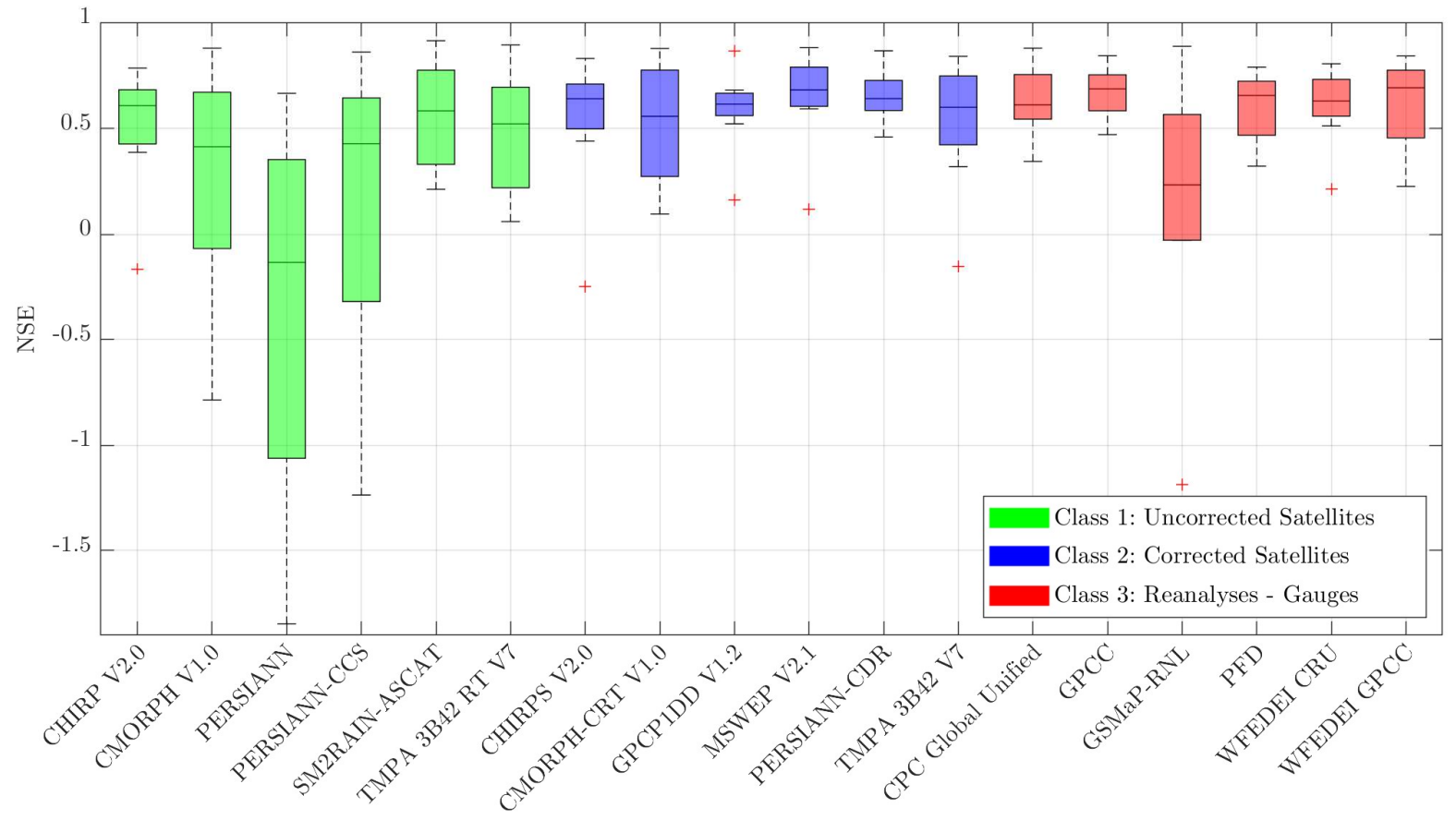

947 Figure 5. Boxplots of the NSE values (from model validation) at basin outlets for all 948 precipitation datasets over the 8 river basins. Outliers are represented by red crosses. 


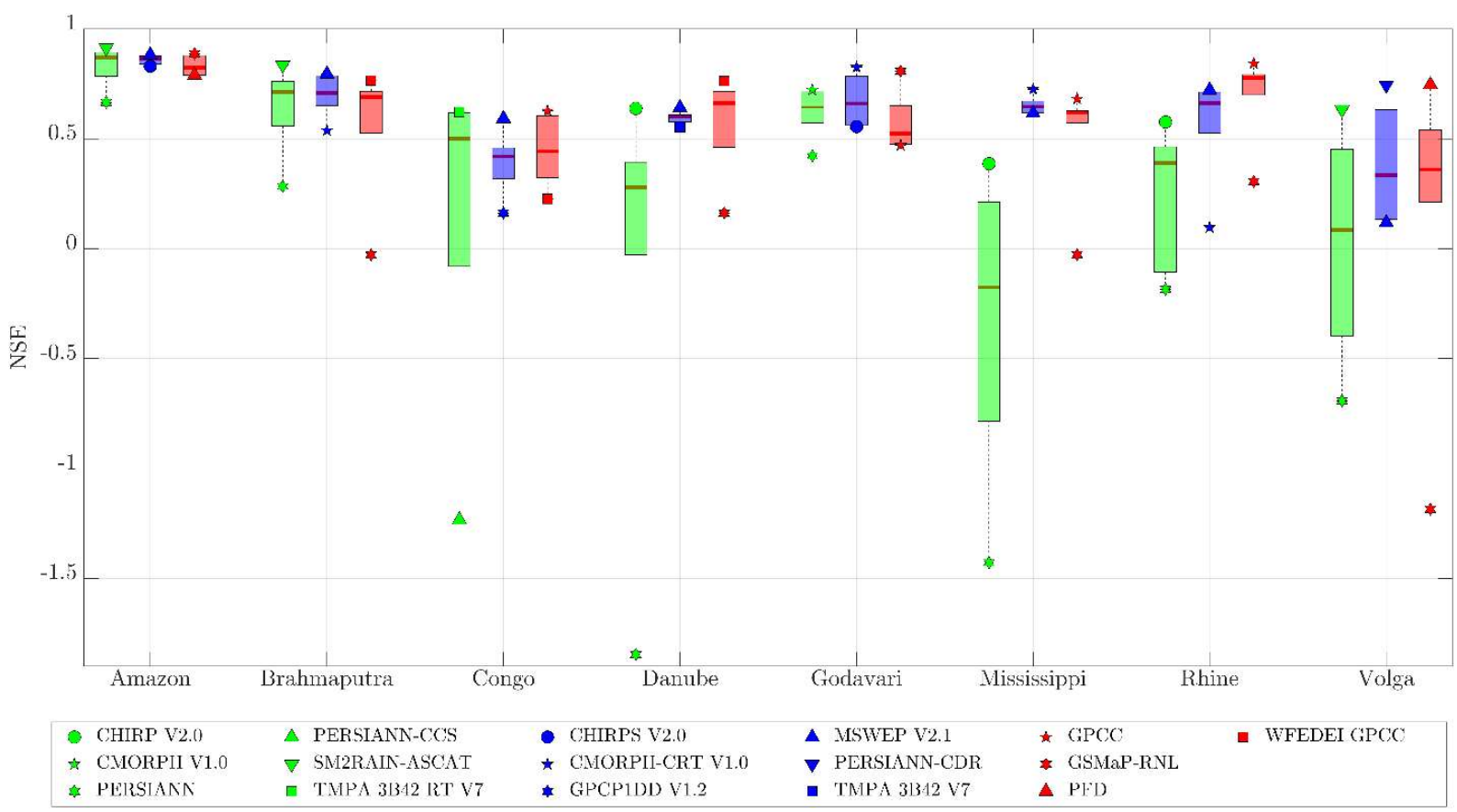

951 Figure 6. Boxplots of the NSE values (from model validation) at basin outlets divided in dataset 952 classes (Class 1, 2 and 3 visualized in green, blue and red respectively). In addition, datasets 953 providing the maximum and minimum NSE for each class on each basin are represented as the 954 boxplot extremes

955 

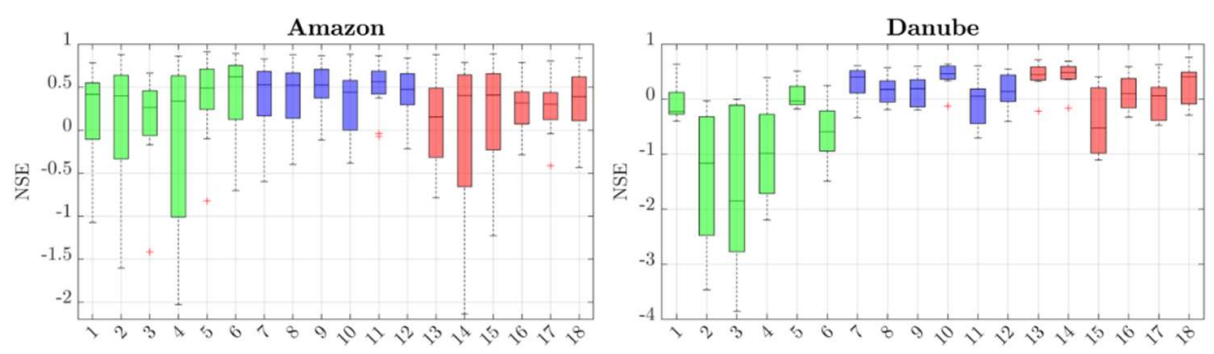

\begin{aligned} \hline$\# &$ Dataset name \\ \hline 1 & CHIRP V2.0 \\ 2 & CMORPH V1.0 \\ 3 & PERSIANN \\ 4 & PERSIANN-CCS \\ 5 & SM2RAIN-ASCAT \end{aligned}
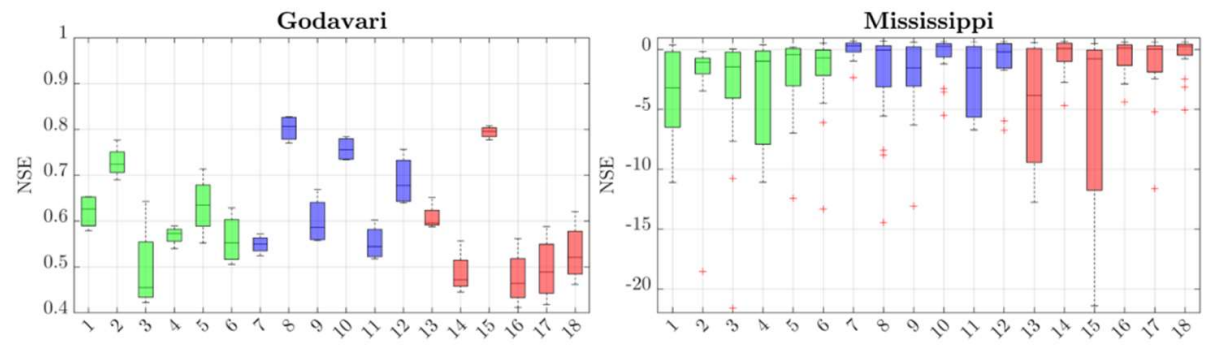

5 SM2RAIN-ASCAT

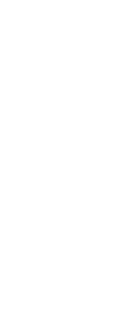

Rhine

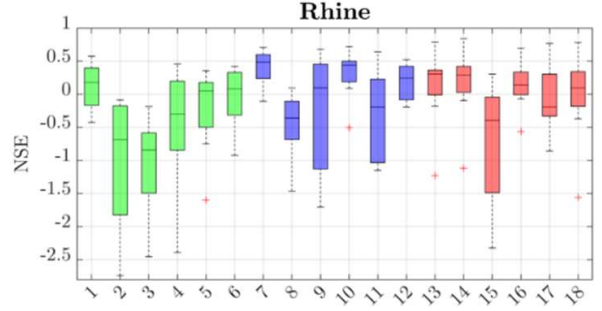

- Class 1: Uncorrected Satellites

Class 2: Corrected Satellites

Class 3: Reanalyses - Gauges

\section{TMPA 3B42 RT V7}

7 CHIRPS V2.0

8 CMORPH-CRT V1.0

9 GPCPIDD V1.2

10 MSWEP V2.1

11 PERSIANN-CDR

12 TMPA 3B42 V7

13 CPC Global Unified

14 GPCC

15 GSMaP-RNL

16 PFD

17 WFEDEI CRU

18 WFEDEI GPCC

Figure 7 Boxplots of the NSE values (from model validation) for all precipitation datasets 959 (numbers from 1 to 18 refer to Table 2) over all sensors, both at the outlet and internal locations. 960 Outliers are represented by red crosses. 

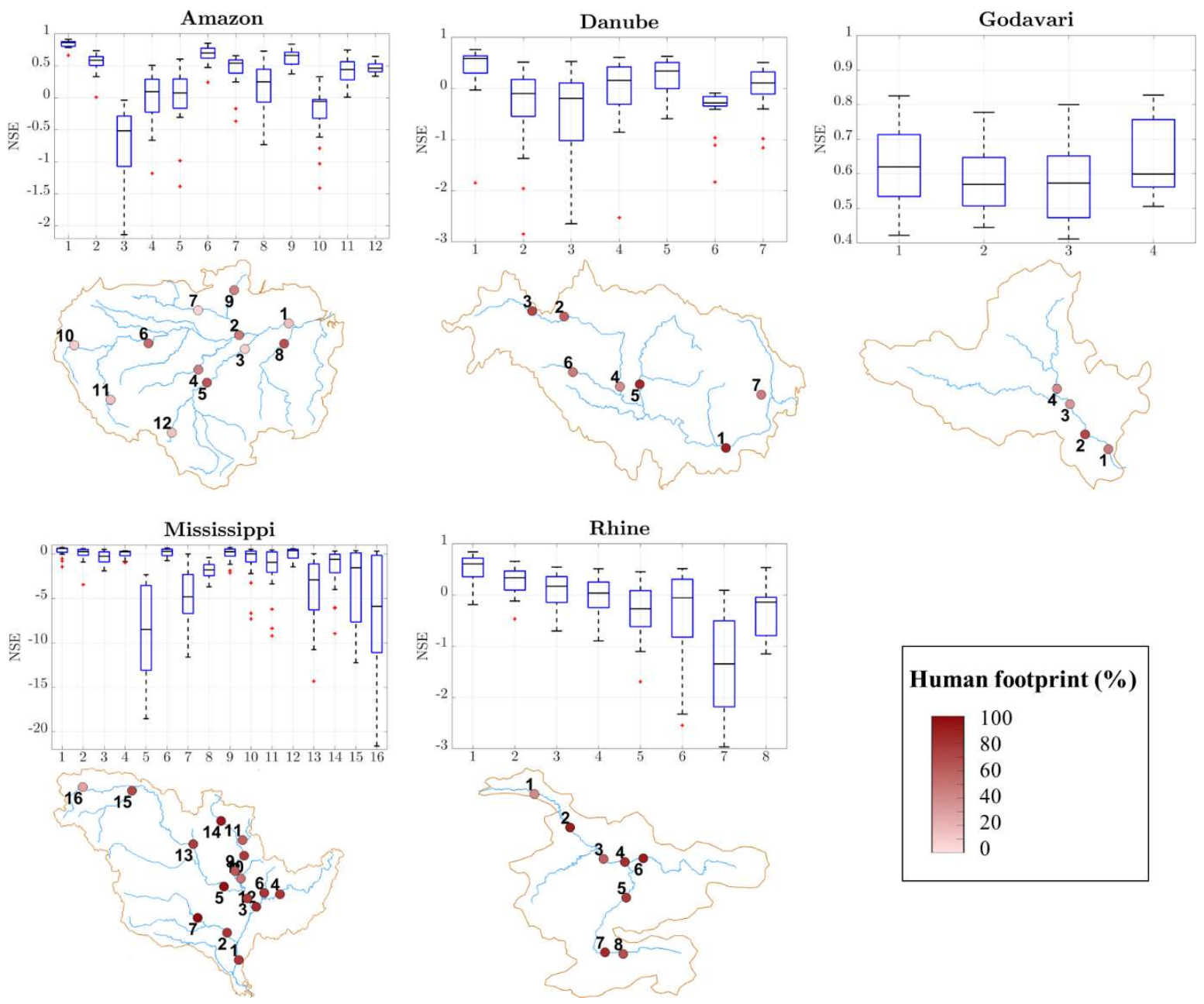

962

Figure 8. Boxplots of the NSE values (from model validation) for all sensor locations, over all precipitation datasets. Outliers are represented by red crosses. 


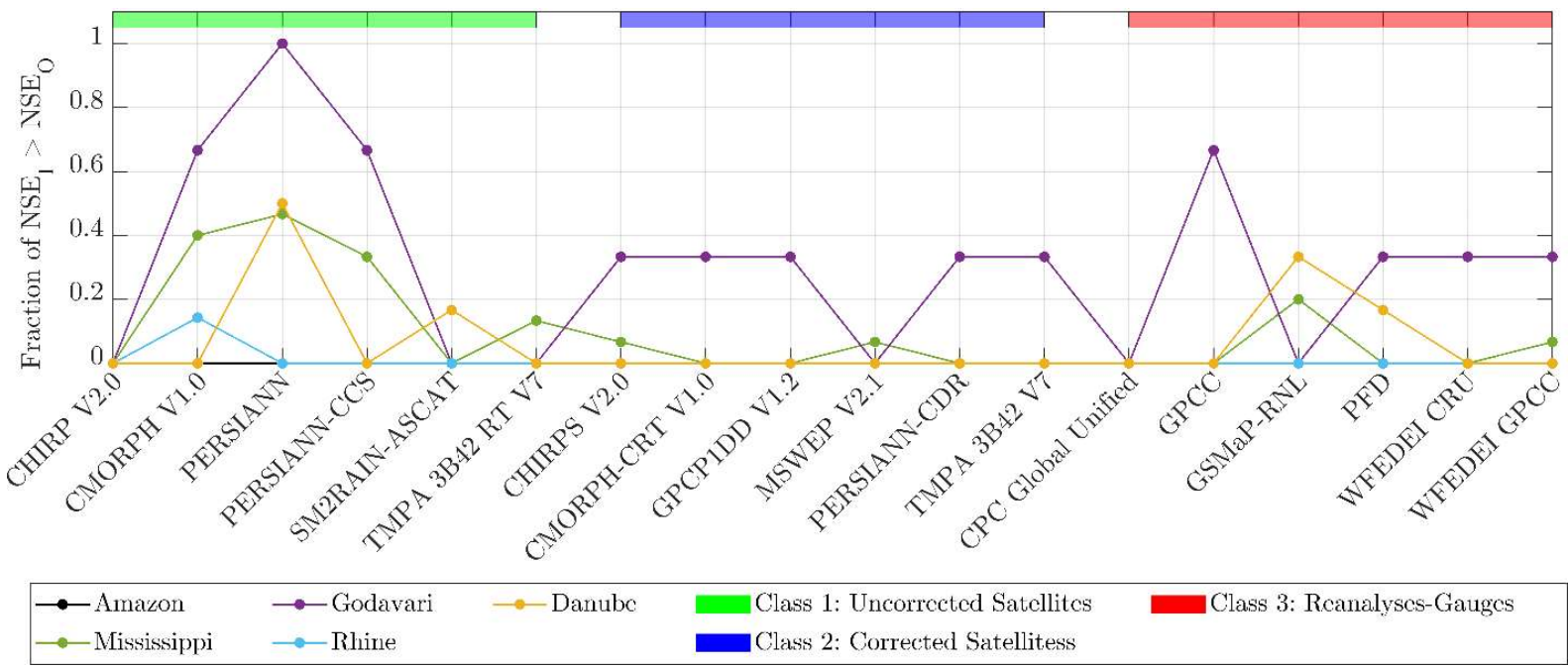

Figure 9. Percentage of internal sensors with NSE values higher than the one at basin outlet for all precipitations datasets on the 8 river basins. 


\section{Uncorrected Satellites Corrected Satellites Reanalyses and Gauges}
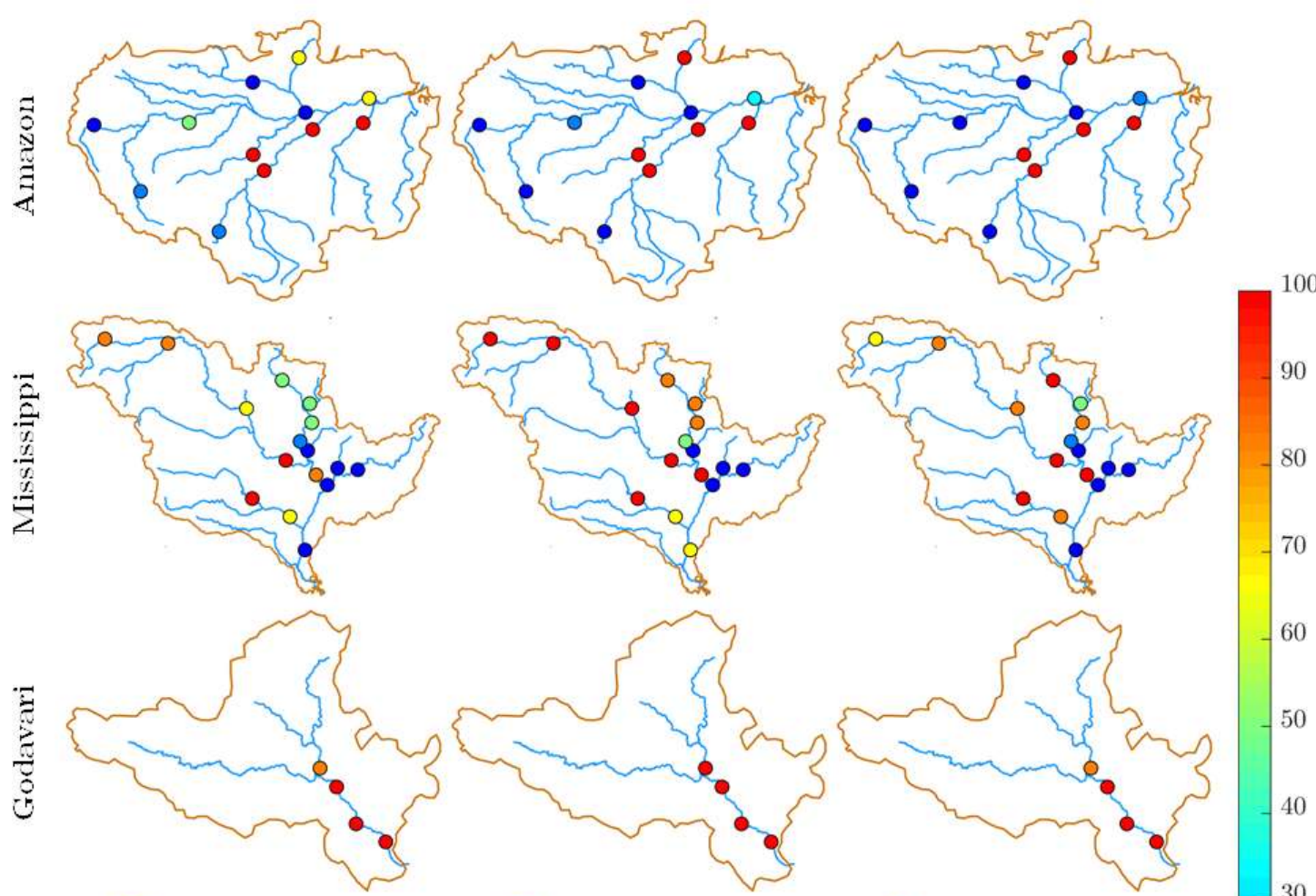

60
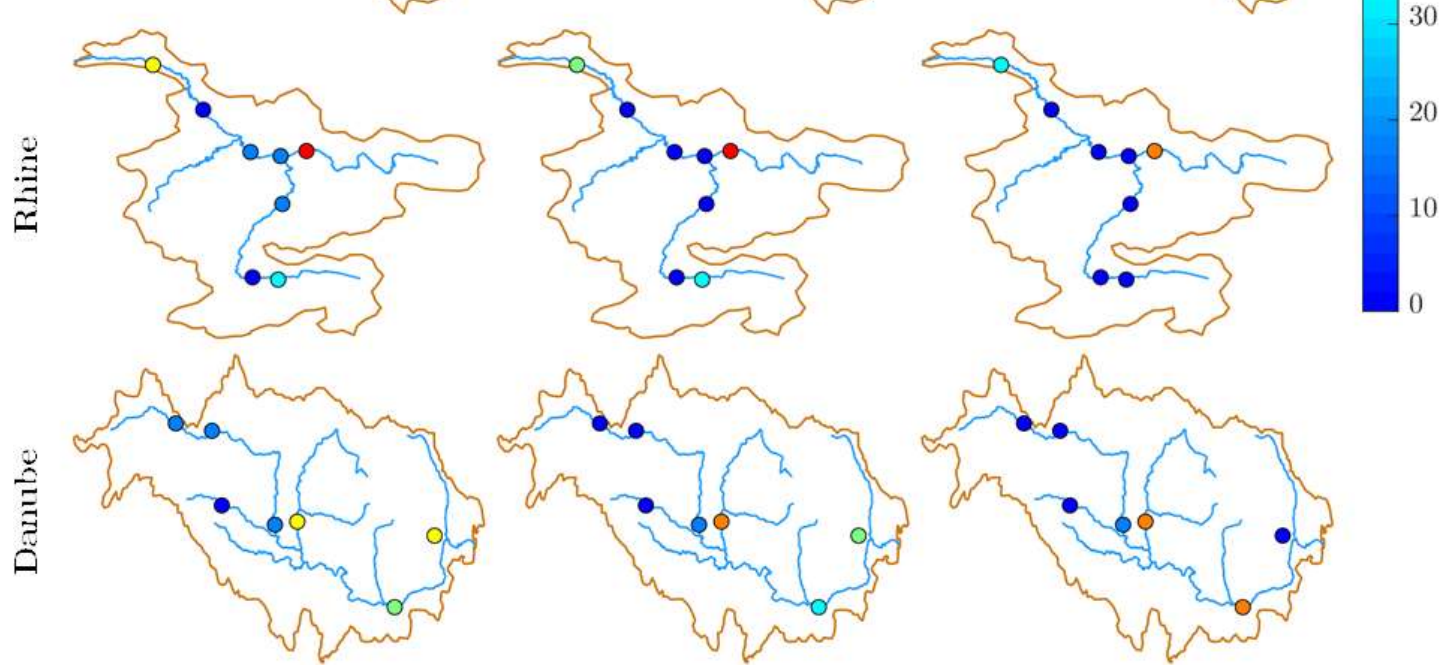

Figure 10. Percentage of precipitation datasets (divided by classes) with Bias index higher than 1 (overestimation) for each sensor location. Percentage of $100 \%$ indicates that all datasets overestimate observed flow at a given sensor location. 

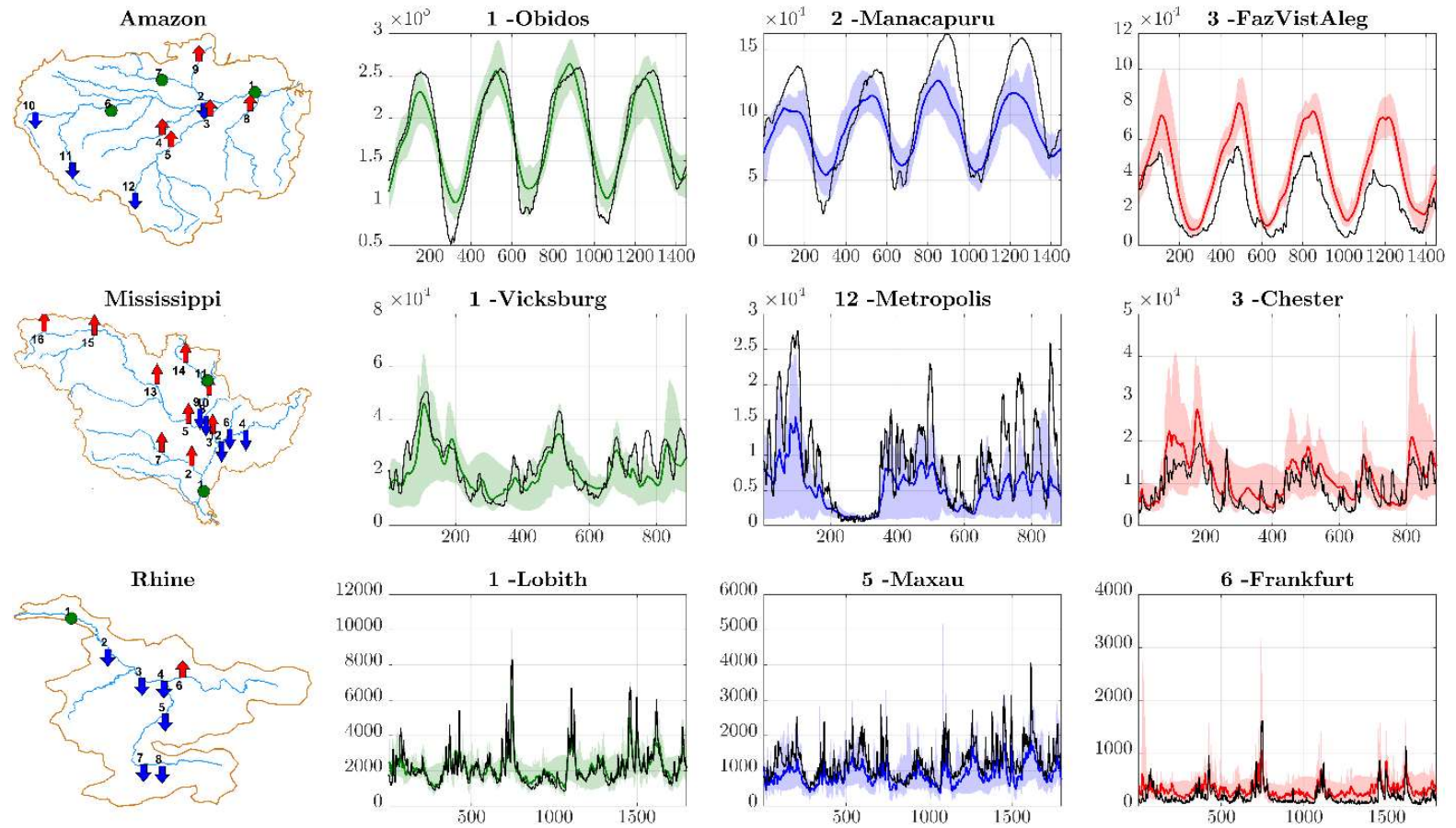

Figure 11. On the left side: average values of the Bias index for each sensor location on three selected river basins. Red and blue arrows indicate average Bias index value higher than 1.1 (overestimation) and lower than 0.9 (underestimation). The green circles indicate average Bias index between 0.9 and 1.1. On the right side: ensemble of simulated flow for all precipitation datasets for three specific locations represented in the maps on the left side. Red and blue ensembles indicate overestimation and underestimation, respectively. 


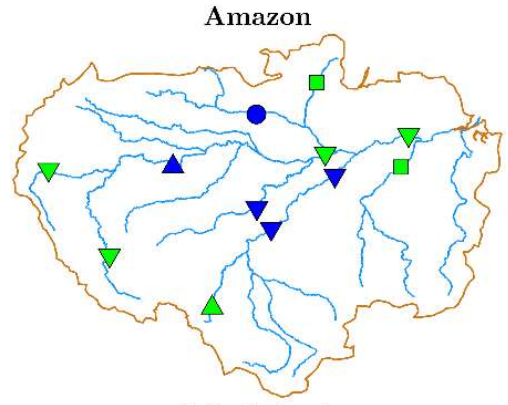

Mississippi

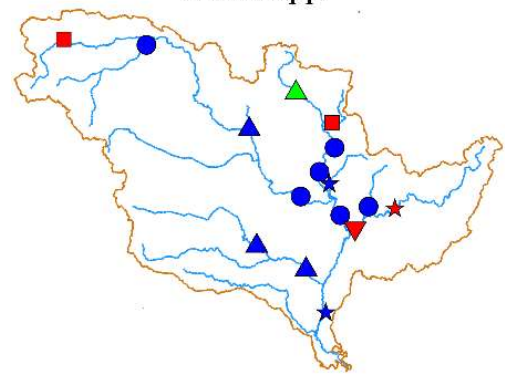

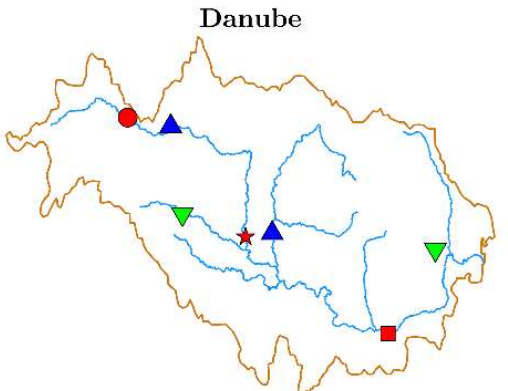

Rhine

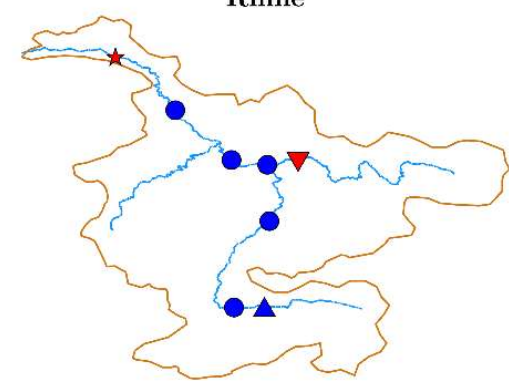

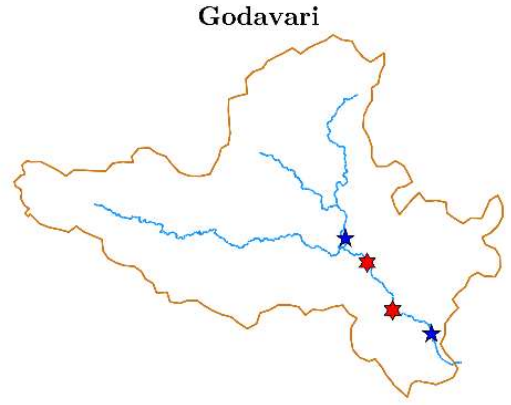

$\triangle$ PERSIANN-CCS

$\nabla$ SM2RAIN- $A S C A T$

$\square$ TMPA $3 B / 2$ R'T VT

- CHIRPS Vi.0

^ CMORPh-CRT V1.0

A MSWEP V2.1

v persian.corr

- CPC Global Unified

$\star$ GPCC

* GSMaP-RNL

$\nabla$ hitedat Cru

- WTEDEI GPCC
984

985

986

987
Figure 12. Representation of the precipitation datasets that provided the best NSE values for each river basin. 